\title{
Boundary Circulation at the Exit of the Labrador Sea
}

\author{
Jürgen Fischer, Friedrich A. Schott, ANd MARcus Dengler \\ Leibniz Institut für Meereswissenschaften, Kiel, Germany
}

(Manuscript received 18 July 2003, in final form 16 January 2004)

\begin{abstract}
The deep circulation and related transports of the southern Labrador Sea are determined from direct current observations from ship surveys and a moored current-meter array. The measurements covered a time span from summer 1997 to 1999 and show a well-defined deep boundary current extending approximately out to the 3300-m depth contour and weak reverse currents farther offshore. The flow has a strong barotropic component, and significant baroclinic flow is only found in the shallow Labrador Current at the shelf break and associated with a deep core of Denmark Strait Overflow Water. The total deep-water transport below $\sigma_{\Theta}=27.74 \mathrm{~kg} \mathrm{~m}^{-3}$ was $26 \pm 5 \mathrm{~Sv}\left(\mathrm{~Sv} \equiv 10^{6} \mathrm{~m}^{3} \mathrm{~s}^{-1}\right)$ comprising Labrador Sea Water (LSW), Gibbs Fracture Zone Water (GFZW), and Denmark Strait Overflow Water (DSOW). Intraseasonal variability of the flow and transport was high, ranging from 15 to $35 \mathrm{~Sv}$, and the annual means differed by $17 \%$. A seasonal cycle is confined to the shallow Labrador Current; in its deeper part, where the mean flow is still strong, no obvious seasonality could be detected. The transport of the interior anticyclonic recirculation was estimated from lowered acoustic Doppler current profiler stations and geostrophy, yielding about $9 \mathrm{~Sv}$. Thus, the net deep-water outflow from the Labrador Sea was about $17 \mathrm{~Sv}$. The baroclinic transport of GFZW and DSOW referenced to the depth of the isopycnal $\sigma_{\Theta}=$ $27.80 \mathrm{~kg} \mathrm{~m}^{-3}$ is only about one-third of the total transport in these layers. Longer-term variations of the total transports are not represented well by the baroclinic contribution.
\end{abstract}

\section{Introduction}

The near-surface circulation of the Labrador Sea is cyclonic and consists of two components. One is the shallow rim current made up by the East and then West Greenland Current along the northern margin and on the southern side by the Labrador Current. It is characterized by low salinity and cold temperatures, due to freshwater and ice influx from the coasts. Hence, part of the driving of this shallow component is thermohaline, through the cross-shelf density gradient, and would exist indepently of the wind forcing by the cyclonic wind stress curl. Its transports are summarized in Loder et al. (1998). While the shallow component of the boundary current $(\mathrm{BC})$ is located on the shelf where it is concentrated in an inner and an outer branch on the Labrador side (Narayanan et al. 1996), this remotely wind-forced current hugs the continental slope. Along its cyclonic path it advects water out of the Irminger Sea into the Labrador Sea, causing an interim salinity maximum at 100-500-m depth underneath the fresh surface waters. The shelf and the slope parts of the Labrador Current are separated by a water mass front that slopes upwards toward the open ocean and the surface

Corresponding author address: Dr. Jürgen Fischer, Leibniz Institut für Meereswissenschaften, Düsternbrooker Weg 20, 24105 Kiel, Germany.

E-mail: jfischer@ifm-geomar.de location of which coincides roughly with the velocity maximum over about the 2500-m depth contour (Lazier and Wright 1993). When arriving at the southern exit of the Labrador Sea, a substantial fraction of the Labrador Current, estimated at 6-10 Sv $\left(\mathrm{Sv} \equiv 10^{6} \mathrm{~m}^{3} \mathrm{~s}^{-1}\right)$ by Petrie and Buckley (1996) leaves the region through Flemish Pass, which has a saddle depth of $1100 \mathrm{~m}$, and a smaller fraction of the low-salinity shelf water circulates around Flemish Cap.

At depth, the Labrador Sea is a thoroughfare for the deep western boundary current (DWBC). At the deepest levels it is supplied by freshly ventilated overflow waters from Denmark Strait that increase in transport along the East Greenland coast by entraining waters out of the environment and form the lower North Atlantic Deep Water (INADW). Above it the DWBC carries water from the Northeast Atlantic overflow regime that has entered the western basin through the Charlie Gibbs Fracture Zone (CGFZ) and is older and higher in salinity through Mediterranean Water admixtures. In the classic nomenclature it was called middle NADW, and in more recent times it has been called Gibbs Fracture Zone Water (GFZW) (Smethie and Swift 1989) after it entered the western basin of the North Atlantic. Both branches of the NADW pass cyclonically around the Labrador Sea and exit around Flemish Cap.

The Labrador Sea Water (LSW) fills the basin between the two deep-water masses and the warmer and 
more saline Irminger Sea Water (ISW) above. It is generated in late winter through convection processes that show large interannual to decadal variability (Lazier 1980; Lazier et al. 2002; Dickson et al. 1996), with maximum depth of more than $2000 \mathrm{~m}$ (Lazier et al. 2002) near OWS Bravo. The shallow part of the LSW can be quickly flushed out of the Labrador Sea with the boundary current (Pickart et al. 1997) and through the 1100-m-deep Flemish Pass. The LSW from the central Labrador Sea recirculates on wide routes to the east, even crossing the Mid-Atlantic Ridge into the eastern basin, as shown first by Talley and McCartney (1982), more recently by tracer observations (Rhein et al. 2002), and was schematically described by Schmitz and McCartney (1993). Regarding the role of LSW production variability on the boundary current variability, recent model studies by Eden and Willebrand (2001) show a delayed (2-3 years) response of the thermohaline circulation to anomalous convection in the Labrador Sea.

Various studies to quantify parts of these circulation branches have been carried out. As is obvious from the above-described circulation patterns, geostrophic calculations must suffer from the nonexistence of a level of no motion. The shallow rim currents are cyclonic, the DWBC is cyclonic, and the response to the wind stress curl is also cyclonic and should give rise to a deep-reaching near-barotropic boundary flow. Hence, direct current measurements are important in the region and not very many were available in the past, in particular not from the near-bottom flows. Recently, Lavender et al. (2000) showed this cyclonic circulation around the Labrador Sea based on the displacements of profiling floats. A special puzzle is the mechanism and pathway of a series of permanent recirculation cells adjacent to the boundary current regime and associated transports towards the convection region in the central Labrador Sea (Fischer and Schott 2002; Käse et al. 2001).

Regarding the magnitude and time scales of variability of these various flows the picture is still fairly obscure. Helped by the existence of OWS Bravo, decadal variability of convection intensity and water mass transformation in the central Labrador Sea is long known (Lazier 1980, 1988) and more recently (Lazier et al. 2002; Stramma et al. 2004, hereinafter SKRSYK) but this knowledge does not readily transfer into drainage or DWBC transport variability, only that more or less modified water mass properties exist at the end of a winter for the circulation to transport.

The objective of this study is to quantify the different components of the boundary circulation along the Labrador slope with the main focus on the LSW depth range. Short-term to annual variability of the flow and transports and possible relations to the convection cycle will be evaluated. The results will be put into the perspective of earlier observations to possibly conclude on longerterm trends of water mass properties and transports.

\section{Methods}

The area of interest is the boundary current regime in the southern Labrador Sea, just north of the influence of the North Atlantic Current and its deepest penetration into the Labrador Sea, the "Northwest Corner." In the foreground of this investigation are transports of the deep boundary current system near the exit of the Labrador Sea and their longer-term variability. The database for this observational program comprises shipboard observations, moored current-meter arrays, and data obtained by profiling floats. Section location and mooring positions are summarized in Fig. 1.

\section{a. Shipboard measurements}

Shipboard measurements were carried out along a section perpendicular to the topography and parallel to the boundary current array (hereinafter the $53^{\circ} \mathrm{N}$ section), which intersects the $1000-\mathrm{m}$ isobath near $52^{\circ} 52^{\prime} \mathrm{N}$, $51^{\circ} 35.4^{\prime} \mathrm{W}$. There were six surveys with different horizontal resolution and section extent. The cruises were (Table 1): RV Valdivia cruise VA-161 (July-August 1996), RV Meteor cruise M39/4 (July-August 1997), RV Valdivia cruise VA-172 (July-August 1998), RV Meteor cruise M45/3 (July-August 1999), and RV Meteor cruise M50/1 and M50/2 (May-June 2001). The measurements during 1997 were constrained by ship time and the section ended at the position of the outermost mooring (K16) rather than being extended deeper into the basin.

For hydrographic measurements a Neil Brown Mark III CTD or a Seabird CTD was used, supported by a 24-bottle rosette sampler for calibration purposes (mainly for salinity and oxygen). The CTD thermometers were calibrated before the cruise and the temperature accuracy is estimated to $2 \mathrm{mK}$, confirmed by reversing thermometers. Salinity was calibrated versus water samples resulting in an accuracy of 0.002 . All profiles were down to about $20 \mathrm{~m}$ above the bottom.

Three different types of lowered acoustic Doppler current profilers (LADCPs) were attached to the rosette frame, a newer generation $150-\mathrm{kHz}$ broadband ADCP (Phase III, 1996 and 1997), a narrowband ADCP during 1997 (at some stations), and during 1999 and the 2001 Meteor legs. Some stations during the 1998 Valdivia cruise were carried out with two $300-\mathrm{KHz}$ Workhorse ADCPs oriented in opposite directions. For the LADCP data processing see Fischer and Visbeck (1993), who estimated the accuracy of individual current profiles at $5 \mathrm{~cm} \mathrm{~s}^{-1}$. This and the other error contributions are primarily random from station to station, and their effect on transport estimates will be reduced when averaging over several profiles. However, all direct current observations contained tidal contributions that were eliminated (see below) prior to transport calculations. 

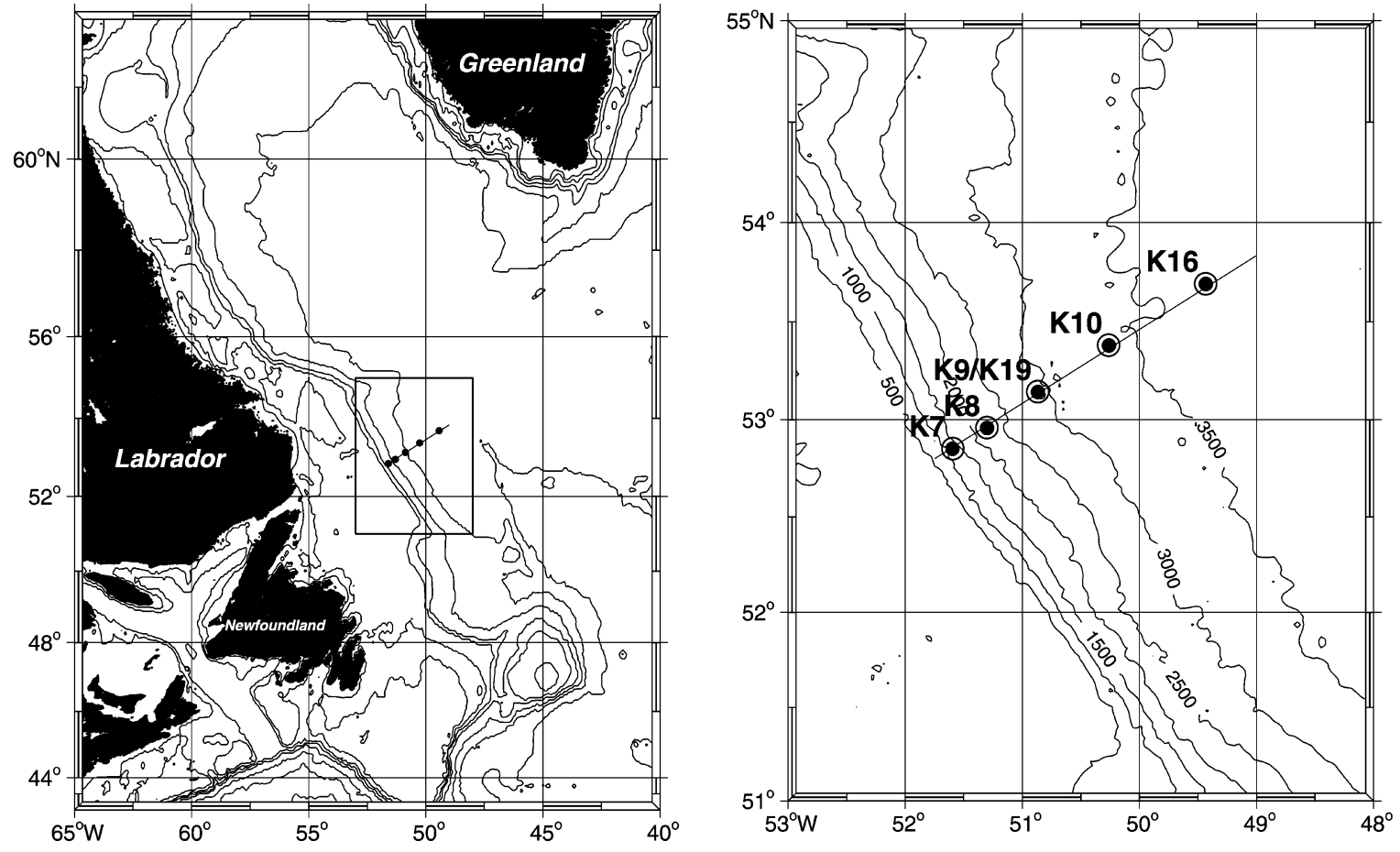

FIG. 1. (right) Section orientation and mooring locations at $53^{\circ} \mathrm{N}$ in the Labrador Sea, and (left) the topography of the Labrador Sea ( $2^{\prime}$ resolution).

\section{b. Moored array}

The moored array was designed on the basis of previous knowledge from shipboard current observations, geostrophic sections, and deep float trajectories. Furthermore, the location at $\sim 53^{\circ} \mathrm{N}$ (Fig. 1) was chosen to be downstream of the area of most likely convection (The Lab Sea Group 1998) and in a region with convenient topography, that is, steep slopes and no upstream topographic humps. The nearshore mooring was deployed $10 \mathrm{~km}$ seaward of the $500-\mathrm{m}$ depth contour with the other four moorings at 30, 70,120, and $185 \mathrm{~km}$ offshore relative to that isobath.

The array was instrumented with ADCPs in the near- surface layer, and a combination of rotor current meters (RCMs) and acoustic current meters (ACMs) in deeper layers (Fig. 2). Only one of the records was from an older type of RCM (K19, 1100-m depth); all other instruments performed a vector decomposition prior to averaging and subsequent storage of the currents. In total, 29 current meters were deployed, of which 26 returned full records. Three current meters had no data because of technical failures; these are not included in Fig. 2. All four ADCPs had record-length datasets. Another important aspect of the array was the ability to measure water mass characteristics by a number (10) of temperature-salinity sensors (SEACATs and MICRO-

TABLE 1. Transports in water mass layers $\left(10^{6} \mathrm{~m}^{3} \mathrm{~s}^{-1}\right)$ from LADCP measurements. Minus sign indicates southward flow/transport.

\begin{tabular}{|c|c|c|c|c|c|c|c|}
\hline Cruise & Year & LSW-BC ${ }^{a}$ & GFZW-BC & DSOW-BC & LSW-RC $^{b}$ & GFZW-RC & DSOW-RC \\
\hline VA-161 & 1996 & -8.1 & -10.4 & -4.7 & 11.6 & 3.4 & - \\
\hline M39/4 & 1997 & -12.7 & -5.3 & - & - & - & - \\
\hline VA-172 & 1998 & -8.3 & -8.1 & -3.9 & 4.5 & - & - \\
\hline M45/3 & 1999 & -7.9 & -6.4 & -3.3 & 1.9 & - & - \\
\hline M50/1 & 2001 & -11.4 & -11.9 & -4.9 & 5.1 & 5.6 & 1.2 \\
\hline Mean $^{\mathrm{c}}$ & - & $-9.7 \pm 2.2$ & $-8.4 \pm 2.7$ & $-4.2 \pm 0.7$ & $5.8 \pm 4.1$ & - & - \\
\hline Alld $^{\mathrm{d}}$ & - & -10.7 & -9.4 & -5.3 & 5.6 & 3.1 & 0.9 \\
\hline Geovel $^{e}$ & 1996-2001 & -11.4 & -8.4 & -3.4 & 4.4 & 3.7 & 1.2 \\
\hline Array & 1997-99 & -11.4 & -9.4 & -4.4 & - & - & - \\
\hline
\end{tabular}

${ }^{a} \mathrm{BC}$ for boundary current.

${ }^{\mathrm{b}} \mathrm{RC}$ for recirculation.

${ }^{\mathrm{C}}$ Mean and standard deviation.

${ }^{\mathrm{d}}$ From composite of all LADCP stations.

${ }^{\text {e }}$ From geostrophy referenced to $1500-\mathrm{m}$ float and current-meter currents; see text. 


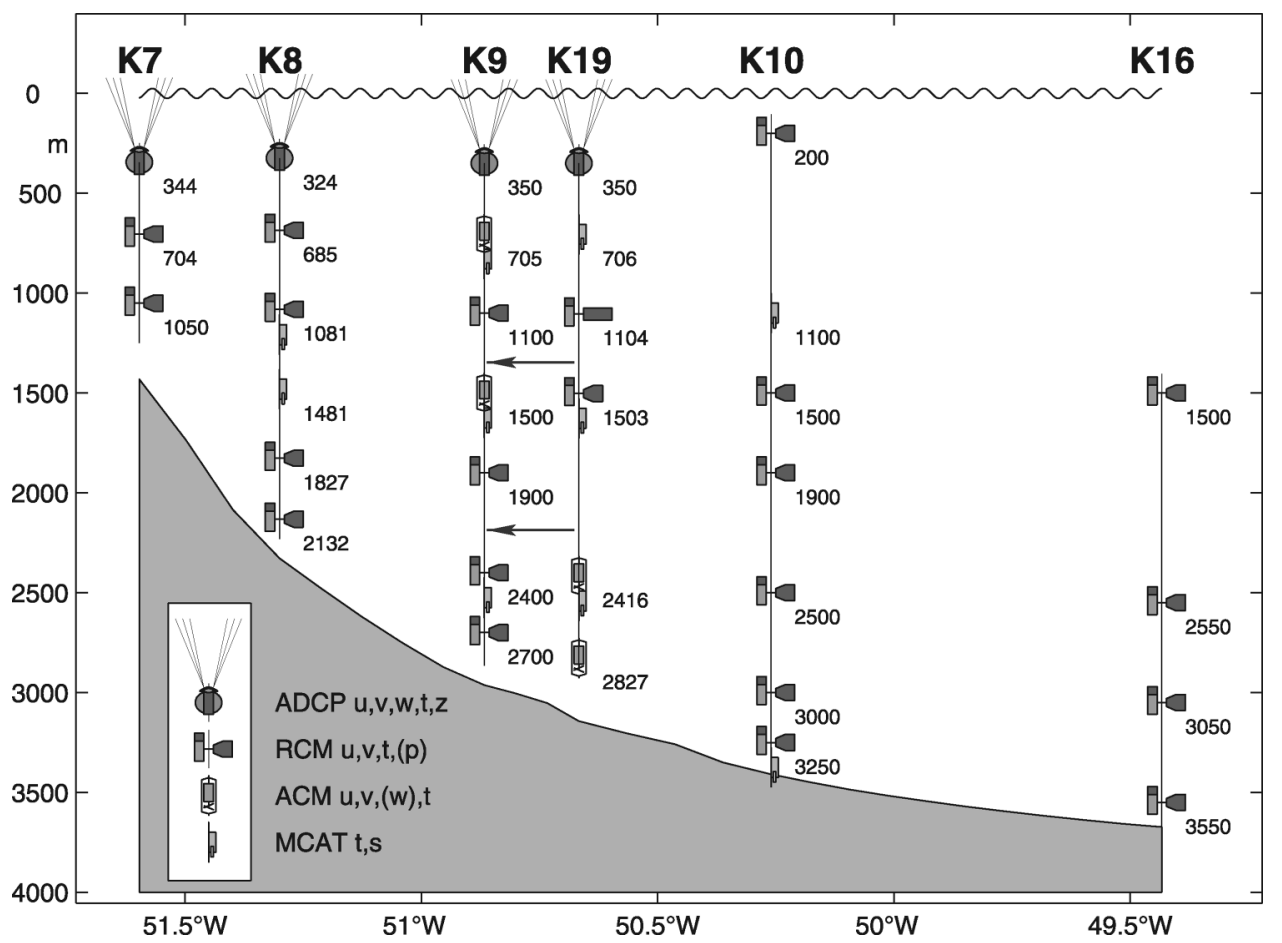

FIG. 2. Instrumentation of the $53^{\circ} \mathrm{N}$ array; instrument type and measured variables are included. Note moorings K9 and K19 were at the same location, with K19 plotted at a small offshore distance (arrows) for convenience.

CATS). The array was deployed for almost exactly two years from mid-July 1997 to mid-July 1999 with the exception of mooring $\mathrm{K} 9$, which was recovered after a year and almost instantaneously redeployed (mooring K19) at the same position (Fig. 2), but with slightly different instrumentation.

\section{Observations}

\section{a. Float data}

Lagrangian profiling floats drifting within the deep boundary current are used to relate the localized current meter information to the general boundary current structure along the Labrador shelf and for referencing the mean geostrophic current section. For this purpose 15 floats were deployed upstream and prior (March 1997) to the mooring deployments. The floats were ballasted to drift on the $1500-\mathrm{m}$ depth level. The trajectories of these floats and long term current meter means are used to construct a mean horizontal boundary current profile in the LSW core layer (Fig. 3). For an earlier version, based on the float data alone, see also Fischer and Schott (2002). The transformation of Lagrangian data into Eulerian averages is not trivial in general (Davis 1991). Errors were estimated for a similar dataset in the Labrador Sea (Straneo et al. 2003) and for surface drifters (Jakobsen et al. 2003) in the northern North Atlantic including the Labrador Sea. Both estimates conclude that this error can be neglected even in the boundary current where they may reach a few centimeters per second. In this study the largest error in the mean flow is introduced by short-term variability.

Using the binned float velocities (here the median of all float velocities in cells of equal water depth $\pm 50 \mathrm{~m}$ ) and the current meter means at the $1500-\mathrm{m}$ level, a best fit of the boundary current structure and the $95 \%$ significance range (on the order of $3 \mathrm{~cm} \mathrm{~s}^{-1}$ ) was determined. Using mean bin velocities instead of median values shows differences only near the end points of the curve with larger excursions for the means. Included are recent current meter means from the period 19972003 at the $53^{\circ} \mathrm{N}$ array. Applying the same fit to the binned float data alone yields a very similar result with the deviations from the best fit of the order of $1 \mathrm{~cm} \mathrm{~s}^{-1}$ (magenta line in Fig. 3). The same holds for the fit solely based on the current-meter records (deviations from best fit as blue line in Fig. 3).

The floats generally followed the depth contours, fastest along the $2500-\mathrm{m}$ isobath and slowing toward shallower and deeper regions, which is supported by the mean current-meter records (Fig. 3) at the 1500-m depth level. There is some indication of a countercurrent (recirculation) offshore of the southeastward boundary current that is visible in both the float data and in the moored records. For comparison moored records (annual and 2-yr means) from 1500-m depth are included; for definition of symbols see the legend in Fig. 3. There is no significant difference between the current-meter 


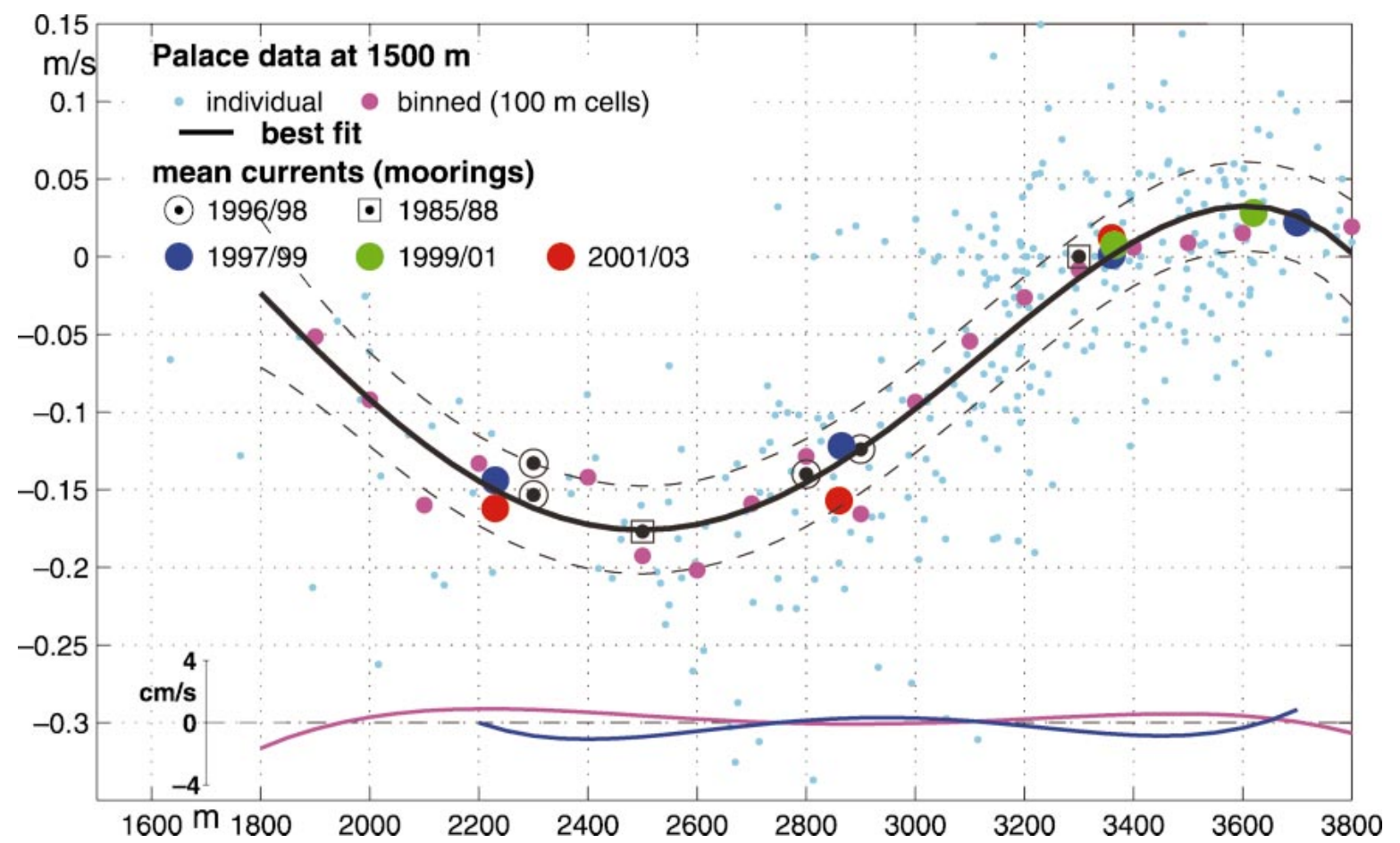

FIG. 3. The Deep Labrador Current determined from Palace float trajectories in the latitude range north of $51^{\circ} \mathrm{N}$ plotted vs water depth (Fischer and Schott 2002). Deployment-long mean currents at $1500 \mathrm{~m}$ from the $53^{\circ} \mathrm{N}$ array (1997-2003) are included as large dots (see legend). Also included are annual means of moored records from Lazier and Wright (1993) farther upstream in the boundary current (squares). The black line shows a best fit to the BC structure (combining float data and current-meter means); dashed line for 95\% significance. Inset shows deviations of fits based on floats alone (magenta line) and current-meter records alone (blue line) from the fit to the combined data.

means and the Deep Labrador Current (DLC) profile determined by a best fit to the combined dataset. One has to keep in mind that the float data are from a relatively large area extending from west of Hamilton Bank to about $51^{\circ} \mathrm{N}$ and that the current-meter records are also from different locations and different deployment periods. This may be interpreted twofold: first, that the boundary current along the Labrador shelf break is a rather stable DWBC controlled by topography and, second, that there is not much interannual variability within the observational period.

\section{b. Shipboard observations at $53^{\circ} \mathrm{N}$}

Six surveys of the boundary current structure and its water masses have been carried out during the summers from 1996 to 2001. These sections generally exhibit similar temperature and salinity structures (Fig. 4); sections from summer 2001 not shown. We define four layers: near surface above $\sigma_{\Theta}=27.74 \mathrm{~kg} \mathrm{~m}^{-3}$ (units are omitted in the following), LSW 27.74 $>\sigma_{\Theta}<27.80$, GFZW in the range 27.80 $>\sigma_{\Theta}<27.88$, and Denmark Strait Overflow Water (DSOW) at $\sigma_{\Theta}>27.88$.

The near-surface layers are dominated by a thin and very fresh layer in which the contribution of melted ice caused the very low salinities. The freshwater signal extends fairly deep at the shelf break in the region of the Labrador Current, and cold temperatures below $2^{\circ} \mathrm{C}$ are still visible at the shallowest stations. The upperlayer volume increases over the observational period as the isopycnal $\sigma_{\Theta}=27.74$ deepens locally by $\sim 200 \mathrm{~m}$ at $49^{\circ} \mathrm{W}$, thereby reducing the volume of classical LSW. The deeper isopycnals appear to be unaffected, and it is reasonable to assume that the reduced convection activity of recent years (Lazier et al. 2002) is responsible for this behavior. LSW covers the largest vertical range and is associated with weak gradients in temperature and salinity; potential temperatures of $3.1^{\circ} \mathrm{C}$ and salinities of 34.88 are typical for this layer. The most saline water in the water column is the GFZW, while the coldest component is DSOW. For transport time series (calculated later) in water mass classes defined above, isopycnal depths are required at the temporal resolution of the current-meter data. Because the appropriate data are not available at this temporal resolution, we use mean boundaries (isopycnals defined above) for the deep-water masses. These are based on the hydrographic sections and are used for the subsequent transport determinations from the boundary current array and those derived from the section data (LADCP and geostrophy).

The flow field of both the boundary current and the adjacent return flow was resolved in only three of the six sections, as the existence of the return flow was not known at the earlier cruises. Two sections just covered 

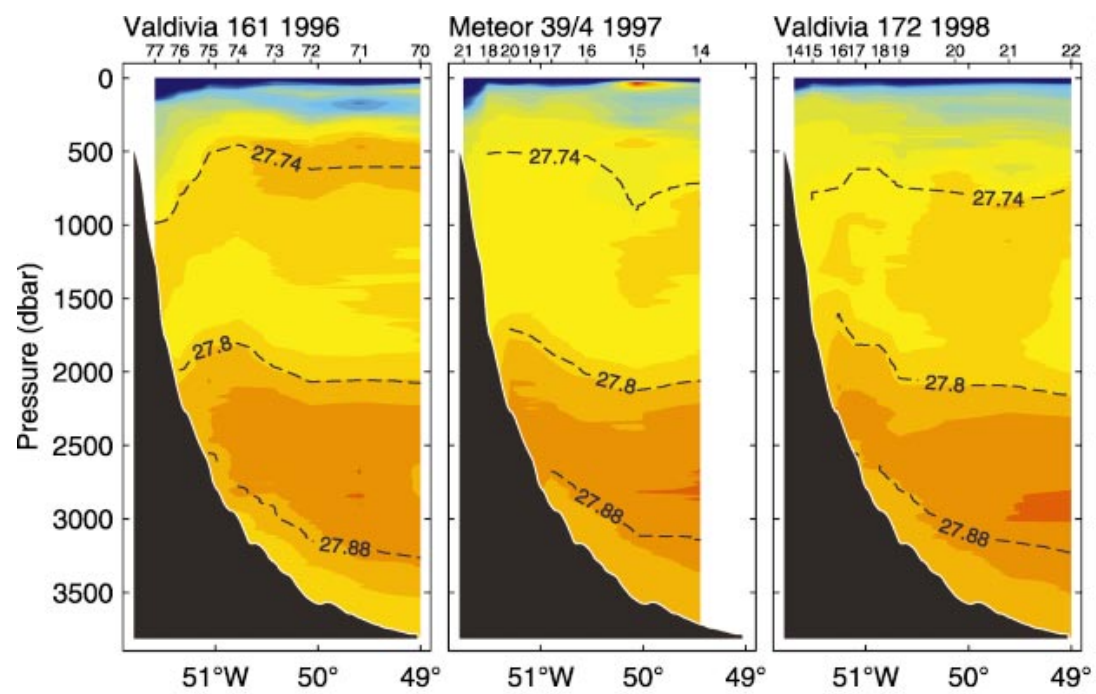

Meteor 45/3 1999
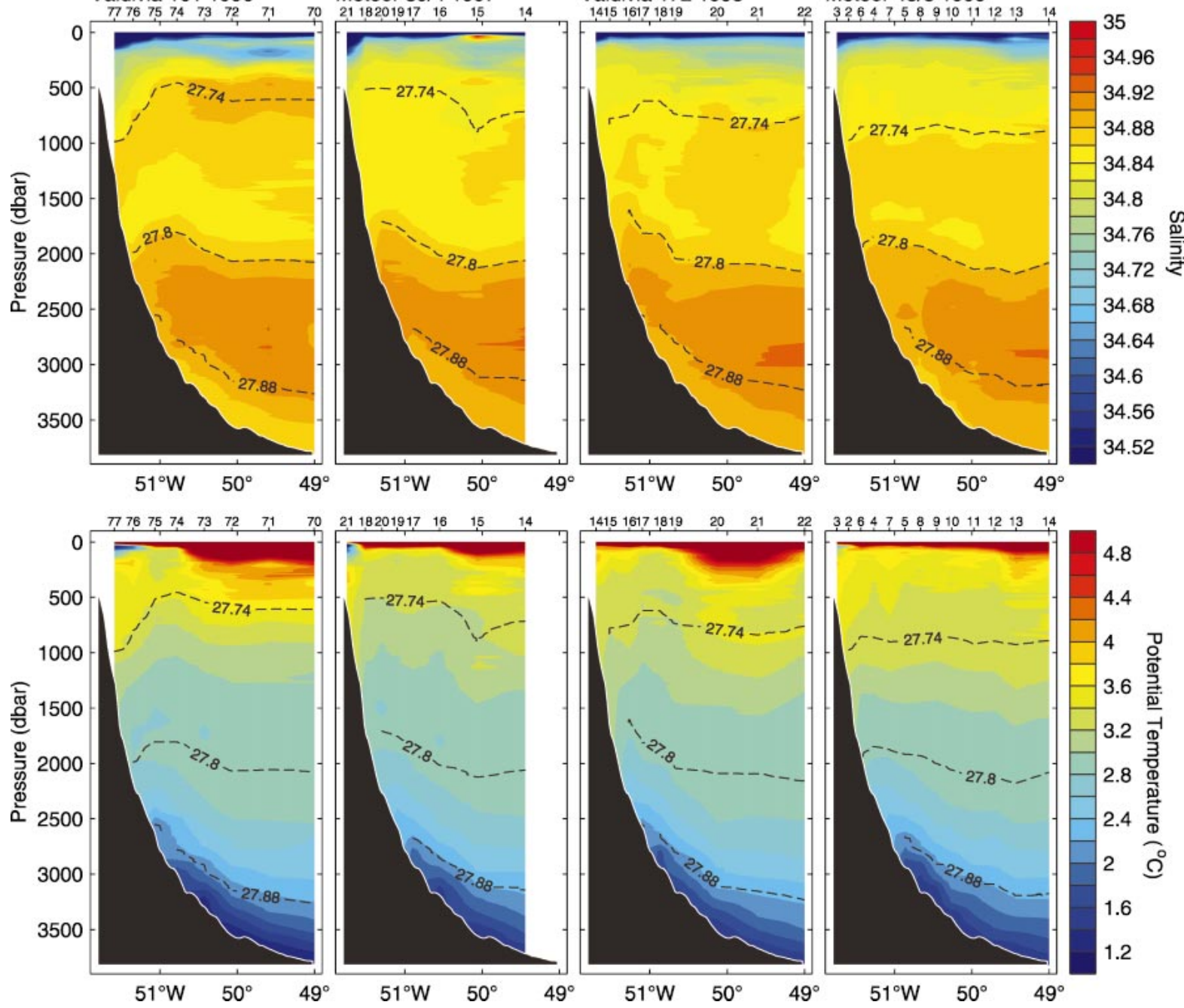

FIG. 4. (top) Salinity and (bottom) potential temperature of the boundary current regime at $53^{\circ} \mathrm{N}$. Cruises are labeled at the top; isopycnals used for water mass boundaries are included.

the flow near the topography (cruises in 1997 and second leg in 2001) because of lack of time. Thus the water mass transports from these LADCP observations (Table 1) are partially incomplete and transports are not calculated if flow regimes are not properly defined. Prior to transport calculations individual current profiles were detided by a prediction of the barotropic tides at the location and time of the profiles. The magnitudes of the subtracted tidal components were in the range $\pm 3 \mathrm{~cm}$ $\mathrm{s}^{-1}$ and in general small in comparison with the boundary current velocities. The model used for this procedure was the FES94 model (LeProvost et al. 1994) and the results were compared with tidal estimates from the moored records in the area (Lohmann 1999), showing reasonable agreement.

Consistent features of the boundary circulation are the nearshore maximum in the upper 500-m layer, associated with the Labrador Current, and a deep current core at water depths below $3000 \mathrm{~m}$ in the DSOW layer.
Within the LSW depth range the current maximum is detached from the topography and is located above 2500-m water depth. Individual current sections were generally completed within a few days and thus are quasi-synoptic snapshots of the high frequency variability (time scales 5-30 days) discussed later. However, the focus of this paper is on the mean structure of the DLC, and we therefore combined all LADCP profiles obtained in the period 1996-2001 to construct one mean flow pattern. The assumption thereby is that there is a mean flow field and superimposed high frequency variability. Averaging over six realizations should then reduce that noise. Altogether 51 LADCP profiles from the six cruises are used to construct the mean field shown in Fig. 5 by using a Gaussian interpolation and extrapolation toward the bottom.

We obtained a well-defined boundary current with a slanting offshore extent; that is the zero isotach is closer to the topography near the surface and is located farther 


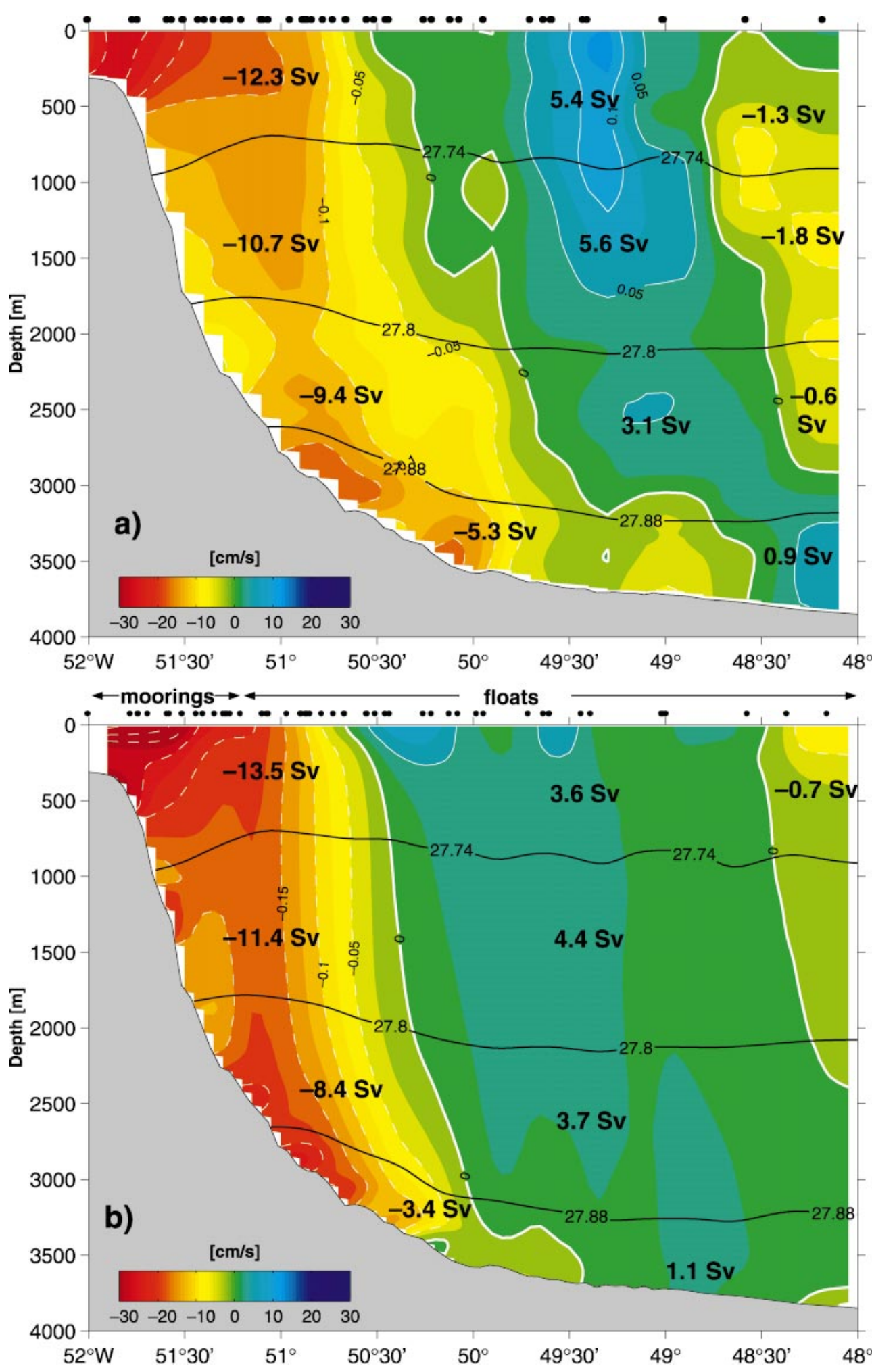

FIG. 5. (a) Boundary current $\left(\mathrm{cm} \mathrm{s}^{-1}\right)$ determined from 51 LADCP profiles measured during 1996-2001. Mean flow direction is $150^{\circ}$, station locations are marked at the top, and transports are in Sverdrups $(\mathrm{Sv} \equiv$ $10^{6} \mathrm{~m}^{3} \mathrm{~s}^{-1}$; boldface numbers) for water masses in between isopycnals (thin black lines). (b) Similarly for mean geostrophic currents referenced by a combination of mooring and float data (see arrows on top of graph); for details see text. 
away from the topography at the deeper (GFZW and DSOW) layers. Here, it should be noted that a horizontal level of no motion does not exist, neither in the boundary current nor in the flow farther offshore. In the LSW and GFZW ranges there is a separation of the current maximum from the topography. Vertically, minimum flow is located roughly between these two water masses near the isopycnal $\sigma_{\Theta}=27.80$. In the lower $500 \mathrm{~m}$ of the water column a current core with more than $20 \mathrm{~cm}$ $\mathrm{S}^{-1}$ is associated with the DSOW, as the enveloping isopycnal $\sigma_{\Theta}=27.88$ shows. Transports obtained by integrating this mean flow field sum up to $25.4 \mathrm{~Sv}$ for the total NADW depth range (Table 1).

A current band of similar width $(100 \mathrm{~km})$ but with reverse direction is located immediately offshore of the boundary current (Fig. 5). This reverse flow has some baroclinic structure with maximum flow from 10 to 15 $\mathrm{cm} \mathrm{s}^{-1}$ near the surface and a reversal at the depth of the isopynal 27.88 defining the DSOW layer. As for the boundary current an intermediate flow minimum is located near $\sigma_{\Theta}=27.80$. In terms of transports (Table 1), the return flow shows about one-half of the boundary current transport in the LSW layer, about one-third in the GFZW layer, but only a small contribution in the DSOW range. The latter is not well defined because there were only a few LADCP stations in that area.

Similarly a mean geostrophic section was determined by averaging the relative geostrophic velocities from the six surveys. The mean section was then referenced by a combination of the float and current-meter data at the 1500-m level (best fit in Fig. 3). Near the shelf break, where the water depth is less than $2400 \mathrm{~m}$ and the data density at the 1500-m level is rather small, we used mean current-meter data from shallower levels as a reference. The result is shown in Fig. 5b. Although there is less vertical shear in the averaged geostrophic section, the main structures and the mean transports (Table 1) are similar to what has been independently derived from the LADCP data. Boundary current transports below $\sigma_{\Theta}$ $=27.74$ were $25.4 \mathrm{~Sv}$ (LADCP mean) and 23.2 Sv (referenced geostrophy), and northwestward transports within the recirculations were 9.6 and $9.2 \mathrm{~Sv}$, respectively. The recirculation in the geostrophic flow field appears somewhat wider and speeds are generally smaller than in the LADCP data; this is due to the smooth structure of the reference velocity and the weak vertical shears in the geostrophic field.

\section{c. Time series data}

In the sequence from the topography toward the interior Labrador Sea the alongshore currents are shown in Figs. 6 and 7 and the current-meter statistics are summarized in Table 2.

All currents were detided by applying a 40-h lowpass filter. Only one bin is shown for each of the ADCPs. In general, the flow is oriented parallel to the topography with the mean direction toward $150^{\circ} \pm 4^{\circ}$ within a very narrow range; accordingly we have chosen a common rotational angle of $150^{\circ}$ as being the representative direction of the boundary current. It should be noted that the axis of maximum variance is also in the direction of the boundary current, even at those locations where a significant mean angle could not be determined because of rather weak and reversing flow (at K10 and K16).

Three types of current meters were used: ADCPs, Aanderaa RCM 8, and acoustic current meters made by Falmouth Scientific Incorporated (FSI). The accuracy of the former two is well known, because these have been used for many years. ADCPs were programmed to achieve an accuracy of about $2 \mathrm{~cm} \mathrm{~s}^{-1}$ for $1-\mathrm{h}$ ensemble averages, which is further increased by longer term averaging because of its almost random nature. Biases are assumed to be negligible. The mechanical current meters (RCM 8) mainly suffer from problems associated with very low currents. However, there are only very few periods with stalled rotors (Table 2) and we have omitted these (e.g., at the end of the 2132-m record of mooring $\mathrm{K} 8$ ) in the calculations of the means and higher-order statistical parameters. The accuracy of the RCMs is estimated at $2 \mathrm{~cm} \mathrm{~s}^{-1}$. For the FSI current meters the situation is somewhat different because these are relatively new instruments. Mean directions are in close agreement with the other instruments, and mean speeds generally agree with other instrument types in corresponding locations. However, some of the FSI current meters showed unreliable low-frequency vertical current components on the order of $5 \mathrm{~cm} \mathrm{~s}^{-1}$. Especially the 2400-m instrument in K19 shows lower horizontal flow than the corresponding RCM during the previous year (K9), while the means of the 1500-m records in K9 and K19 were similar. The reason for this behavior remains uncertain; interannual variability or a bias to low currents by a wrong projection of the horizontal to the vertical components are the candidates. Inspection of the time series in Fig. 6 shows a rather smooth transition from the first to the second deployment, making longer-term variability more likely. Because there are only four FSI current meters in the array, we are rather certain that the effect of a bias toward low currents by, say, $2 \mathrm{~cm} \mathrm{~s}^{-1}$ is not very dramatic for transport calculations in the following.

The records of moorings $\mathrm{K} 7$ and $\mathrm{K} 8$ exhibit the baroclinic flow of the Labrador Current that extends much farther inshore than the location of K7. The near-surface flow of $\mathrm{K} 7$ and $\mathrm{K} 8$ shows both high-frequency fluctuations with time scales of days to about one month and a seasonal modulation that has a seesaw shape rather than a sinusoidal appearance. We observe an almost linear increase of the boundary current flow from April to February in both years and subsequently a rather sudden decrease of the flow by the end of the respective winter. This signal is decreasing with depth and offshore distance and is absent at mooring K9/K19. There is some indication that the seasonal signal in the $\mathrm{K} 7$ and $\mathrm{K} 8$ 

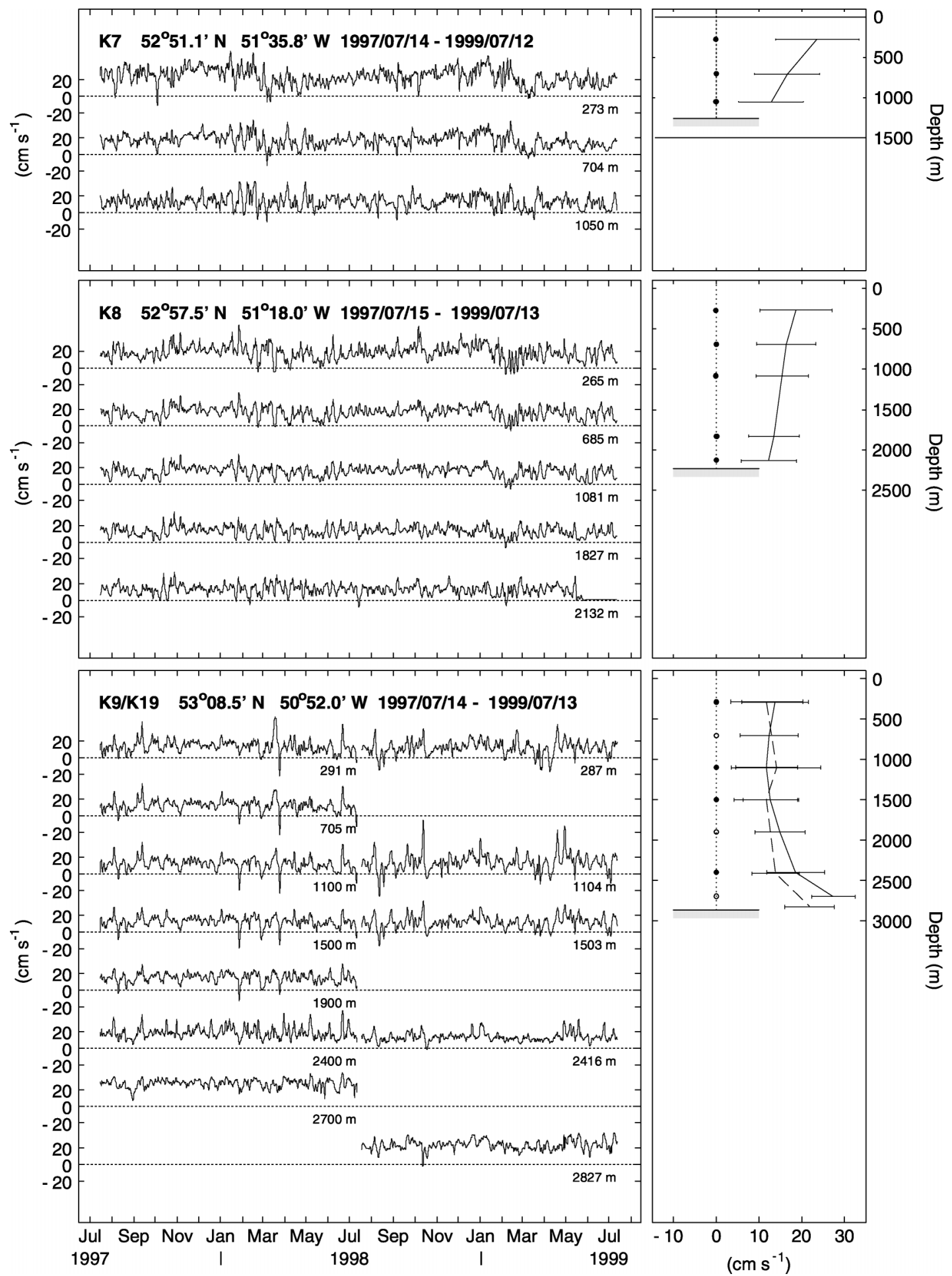

FIG. 6. Time series of alongshore flow (rotated by $150^{\circ}$; $\mathrm{cm} \mathrm{s}^{-1}$ ) at moorings $\mathrm{K} 7$, K8, and $\mathrm{K} 9 / 19$; location and deployment periods are included; the right-hand-side graphs show means and standard deviation bars.

records is more baroclinic than the high-frequency fluctuations, of which the most intense are visible throughout the water column. A more detailed discussion of these phenomena will be given in the variability section.
At mooring K9/K19 the near-surface flow is still quite strong but there is no intensification of the flow toward the surface. Down to the $1500-\mathrm{m}$ level there is almost no difference in the annual means of K9 and K19, re- 


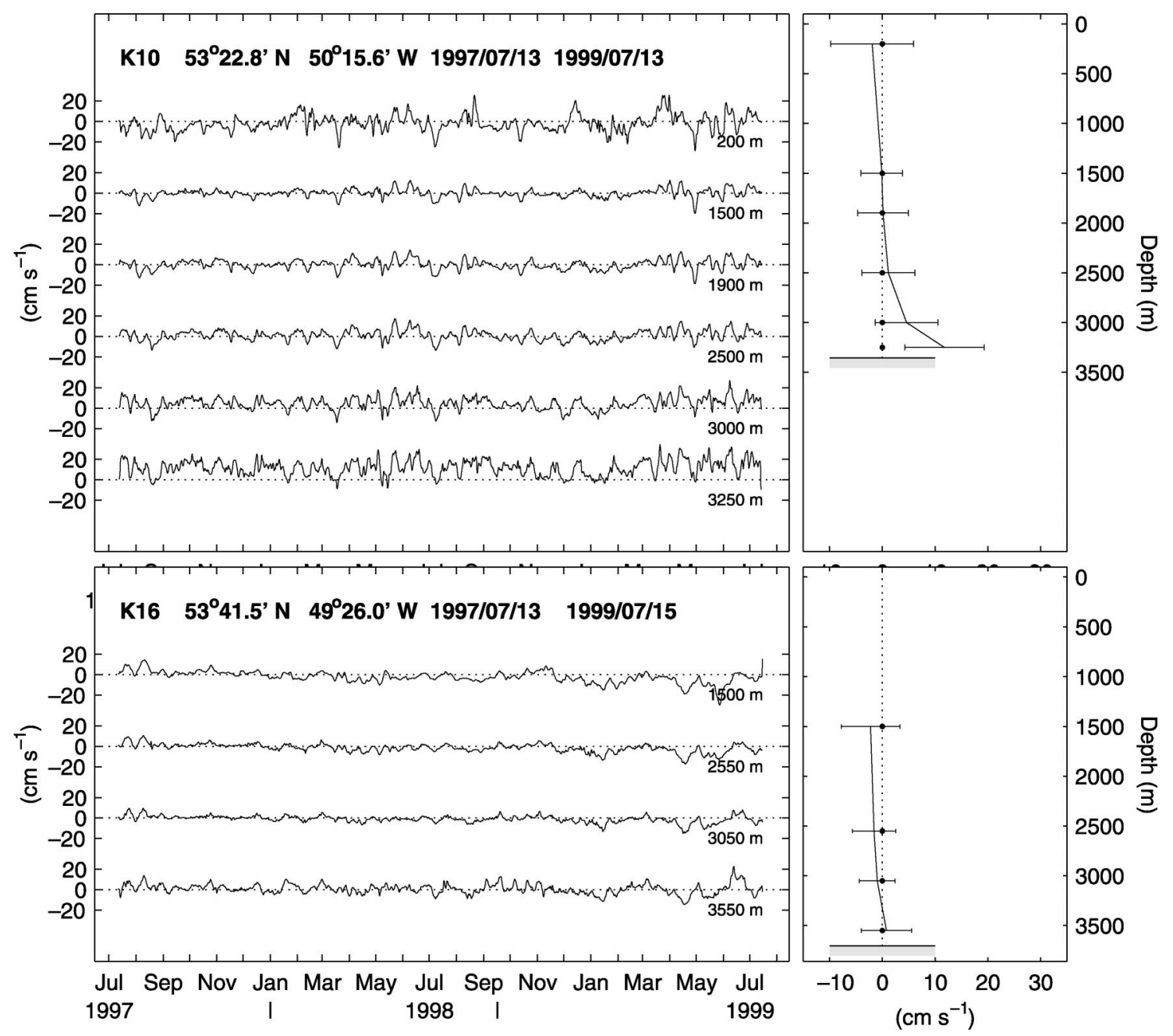

FIG. 7. As in Fig. 6 but for moorings K10 and K16.

spectively, that exceeds $1 \mathrm{~cm} \mathrm{~s}^{-1}$. At depth we observe a strong increase of the flow that is associated with the core of the DSOW. The 2400-m level shows significantly lower mean alongshore flow (lower by $4.8 \mathrm{~cm}$ $\mathrm{s}^{-1}$ ) in the second year and this continues toward the deepest level where the near-bottom flow at K19 is lower by $5.6 \mathrm{~cm} \mathrm{~s}^{-1}$ than that of the previous year (K9). There might be a current decay toward the bottom, as the 2830$\mathrm{m}$ record of mooring K19 was located much closer to the bottom ( $\sim 40 \mathrm{~m}$ above the bottom) than the record of K9 (at 2700-m depth). However, based on the LADCP section data the behavior at the 2400-m level is more likely a temporal effect with less intense flow during 1998-1999.

At mooring K10 the near-surface flow is in opposite direction to the boundary current, which is consistent with the shipboard observations along $53^{\circ} \mathrm{N}$ (Fig. 7). On average, the zero crossing is located at about 1500 $\mathrm{m}$ and that is consistent with the $1500 \mathrm{~m}$ cross-stream profile deduced from the float trajectories (Fischer and Schott 2002), which shows the offshore margin of the boundary current at about the water depth of mooring K10. Toward the bottom the flow intensifies, and the two deepest current meters are clearly within the deep boundary current; the mean flow at the deepest instrument located $\sim 100 \mathrm{~m}$ above the bottom exceeds $10 \mathrm{~cm}$ $\mathrm{s}^{-1}$. Another obvious signal is the amplitude of the highfrequency variability, which is large in the upper and lower layer and somewhat smaller in the LSW/GFZW depth range $(1000-2500 \mathrm{~m})$. There is some indication that the more intense extrema of the flow extend throughout the whole water column, for example, events in March 1998 and April 1999.

Mooring K16 had current meters at and below 1500 $\mathrm{m}$ only and basically served the purpose to define the offshore edge of the deepest part of the BC. In these records there is a weak longer-term signal with flow in the direction of the $\mathrm{BC}$ during the first year and reverse flow during the second year, the latter dominating the biannual mean. The deepest record has zero mean and was well located to define the edge of the BC. None of the records showed a definable mean direction, but a 
TABLE 2. Mean velocities and standard deviations for the whole deployment.

\begin{tabular}{|c|c|c|c|c|c|c|c|c|}
\hline Type & $\begin{array}{c}\text { Depth } \\
(\mathrm{m})\end{array}$ & $\begin{array}{l}\text { Duration } \\
\text { (days) }\end{array}$ & $\begin{array}{c}\bar{\mu} \\
\left(\mathrm{cm} \mathrm{s}^{-1}\right)\end{array}$ & $\begin{array}{c}\sigma_{\mu} \\
\left(\mathrm{cm} \mathrm{s}^{-1}\right)\end{array}$ & $\begin{array}{c}\bar{v} \\
\left(\mathrm{~cm} \mathrm{~s}^{-1}\right)\end{array}$ & $\begin{array}{c}\sigma_{v} \\
\left(\mathrm{~cm} \mathrm{~s}^{-1}\right)\end{array}$ & $\begin{array}{c}\text { EKE } \\
\left(\mathrm{cm}^{2} \mathrm{~s}^{-2}\right)\end{array}$ & $\begin{array}{c}\text { Stalled } \\
(\%)\end{array}$ \\
\hline \multicolumn{9}{|c|}{ Mooring K7; 52 $51.1^{\prime} \mathrm{N}, 5^{\circ} 35.8^{\prime} \mathrm{W}$; 14 Jul 1997-12 Jul 1999; water depth: $1250 \mathrm{~m}$} \\
\hline ACDP & 209 & 728 & 14.45 & 9.84 & -23.50 & 12.21 & 129 & - \\
\hline RCM 8 & 704 & 728 & 9.12 & 6.14 & -13.82 & 7.54 & 47 & 2.6 \\
\hline RCM 8 & 1050 & 728 & 6.61 & 5.82 & -10.90 & 7.73 & 47 & 6.1 \\
\hline \multicolumn{9}{|c|}{ Mooring K8; 52 $57.5^{\prime} \mathrm{N}, 51^{\circ} 18.00^{\prime} \mathrm{W} ; 15$ Jul 1997-13 Jul 1999; water depth: $2230 \mathrm{~m}$} \\
\hline ADCP & 201 & 728 & 7.52 & 10.38 & -18.02 & 11.36 & 121 & - \\
\hline RCM 8 & 685 & 728 & 8.62 & 6.62 & -13.91 & 7.05 & 47 & 2.1 \\
\hline RCM 8 & 1081 & 728 & 8.32 & 5.69 & -13.01 & 6.31 & 36 & 2.8 \\
\hline RCM 8 & 1827 & 728 & 7.05 & 4.95 & -11.54 & 6.27 & 32 & 1.7 \\
\hline RCM 8 & 2132 & 728 & 7.00 & 5.61 & -10.29 & 6.35 & 36 & 9.7 \\
\hline \multicolumn{9}{|c|}{ Mooring K9; $53^{\circ} 08.5^{\prime} \mathrm{N}, 50^{\circ} 52.0^{\prime} \mathrm{W}$; $14 \mathrm{Jul} 1997-12 \mathrm{Jul} 1998$; water depth: $2865 \mathrm{~m}$} \\
\hline ADCP & 227 & 363 & 5.52 & 10.06 & -12.83 & 9.72 & 98 & - \\
\hline FSI-ACM & 705 & 363 & 7.89 & 7.99 & -9.63 & 7.30 & 59 & - \\
\hline RCM 8 & 1100 & 363 & 5.41 & 7.95 & -10.46 & 7.75 & 62 & 5.3 \\
\hline FSI-ACM & 1500 & 363 & 5.92 & 7.56 & -11.13 & 6.96 & 53 & - \\
\hline RCM 8 & 1900 & 363 & 7.19 & 6.88 & -13.10 & 6.34 & 44 & 1.2 \\
\hline RCM 8 & 2400 & 363 & 6.98 & 6.32 & -17.43 & 8.09 & 53 & 0.6 \\
\hline RCM 8 & 2700 & 363 & 12.34 & 5.35 & -24.43 & 5.65 & 30 & 0.1 \\
\hline \multicolumn{9}{|c|}{ Mooring K19; $53^{\circ} 08.5^{\prime} \mathrm{N}, 50^{\circ} 52.0^{\prime} \mathrm{W} ; 17$ Jul 1998-13 Jul 1999; water depth: $2870 \mathrm{~m}$} \\
\hline ADCP & 241 & 361 & 6.75 & 10.80 & -9.69 & 9.90 & 108 & - \\
\hline RCM 5 & 1104 & 361 & 6.97 & 11.77 & -12.14 & 11.26 & 133 & 2.2 \\
\hline RCM 8 & 1503 & 361 & 5.61 & 7.92 & -10.30 & 7.81 & 62 & 2.4 \\
\hline FSI-ACM & 2416 & 361 & 6.89 & 4.91 & -11.89 & 6.27 & 32 & - \\
\hline FSI-ACM & 2827 & 361 & 9.71 & 6.01 & -19.51 & 7.16 & 44 & - \\
\hline \multicolumn{9}{|c|}{ Mooring K10; $53^{\circ} 22.8^{\prime} \mathrm{N}, 50^{\circ} 15.6^{\prime} \mathrm{W} ; 13$ Jul 1997-13 Jul 1999; water depth: $3356 \mathrm{~m}$} \\
\hline RCM 8 & 200 & 730 & 0.04 & 7.90 & 2.21 & 8.76 & 70 & 5 \\
\hline RCM 8 & 1500 & 730 & -0.15 & 4.13 & 0.04 & 3.99 & 17 & 34.9 \\
\hline RCM 8 & 1900 & 730 & -0.25 & 5.03 & -0.28 & 4.93 & 25 & 16.2 \\
\hline RCM 8 & 2500 & 730 & 0.58 & 5.49 & -0.97 & 5.14 & 28 & 11.6 \\
\hline RCM 8 & 3000 & 730 & 2.40 & 6.03 & -3.90 & 6.44 & 39 & 8.8 \\
\hline RCM 8 & 3250 & 730 & 5.79 & 6.72 & -10.26 & 7.79 & 53 & 2.4 \\
\hline \multicolumn{9}{|c|}{ Mooring K16; $53^{\circ} 41.5^{\prime} \mathrm{N}, 4^{\circ} 26.0^{\prime} \mathrm{W} ; 13$ Jul 1997-15 Jul 1999; water depth: $3704 \mathrm{~m}$} \\
\hline RCM 8 & 1500 & 732 & -0.36 & 5.46 & 2.41 & 6.50 & 36 & 6.3 \\
\hline RCM 8 & 2550 & 732 & -0.07 & 4.26 & 1.78 & 5.01 & 22 & 14.3 \\
\hline RCM 8 & 3050 & 732 & 0.33 & 3.88 & 1.31 & 4.33 & 17 & 35.7 \\
\hline RCM 8 & 3550 & 732 & 0.97 & 5.98 & -0.35 & 6.07 & 36 & 15.4 \\
\hline
\end{tabular}

principle axis deconvolution confirmed that the direction of maximum variance is along the topography, either in the $\mathrm{BC}$ direction or reverse. This is also true for the upper records of mooring K10. By the end of the records at K16 we observe some increase in short term barotropic variability that is not apparent in the rest of the record.

\section{d. Temperature records}

The 1500-m-deep potential temperatures at all four moorings show a temperature increase of $\sim 0.1^{\circ} \mathrm{C}$ over the two-year deployment period (Fig. 8), which means that warmer water is penetrating the deep boundary current and is advected past the mooring site. Warming of LSW is also observed in the central Labrador Sea at the main convection site. After several winters with deep convection in the Labrador Sea in the early 1990s the convection depth decreased and the renewal of the deep part of the LSW stopped (SKRSYK; Lazier et al. 2002).
A nearly continuous warming of LSW is observed after the end of the high phase of the North Atlantic Oscillation index.

Coldest temperatures are observed by the instrument in mooring $\mathrm{K} 9$ in the first year, while during the second year K19 and K8 temperatures are more similar. Even warmer temperatures are found at $\mathrm{K} 10$ and $\mathrm{K} 16$, near the periphery of the boundary current or in the recirculation, respectively. This is due to the general structure of the isotherms/isopycnals shown by the shipboard observations (Fig. 4), where we see a doming of the isotherms near the location of K9/19 explaining the relatively cold temperatures at that location. The record at K8 exhibits a temperature development that is also present in the shallower records of station K7, namely, an almost linear increase of the temperature until February followed by a rapid decrease during March. This must be due to dynamical changes, because neither the seasonal warming reached these depths, nor did the wintertime convection penetrate into these layers, at least 

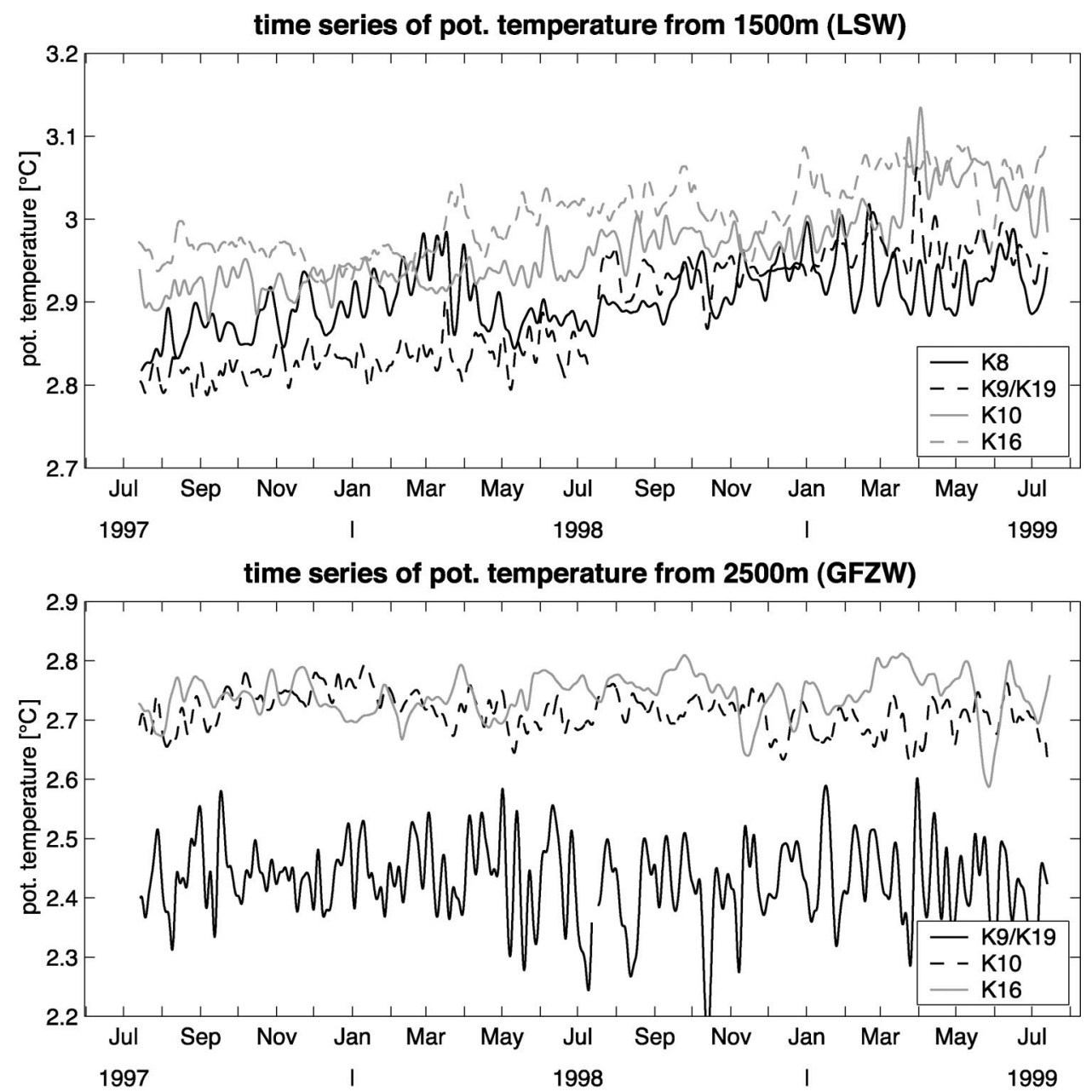

near bottom time series of pot. temperature (DSOW)

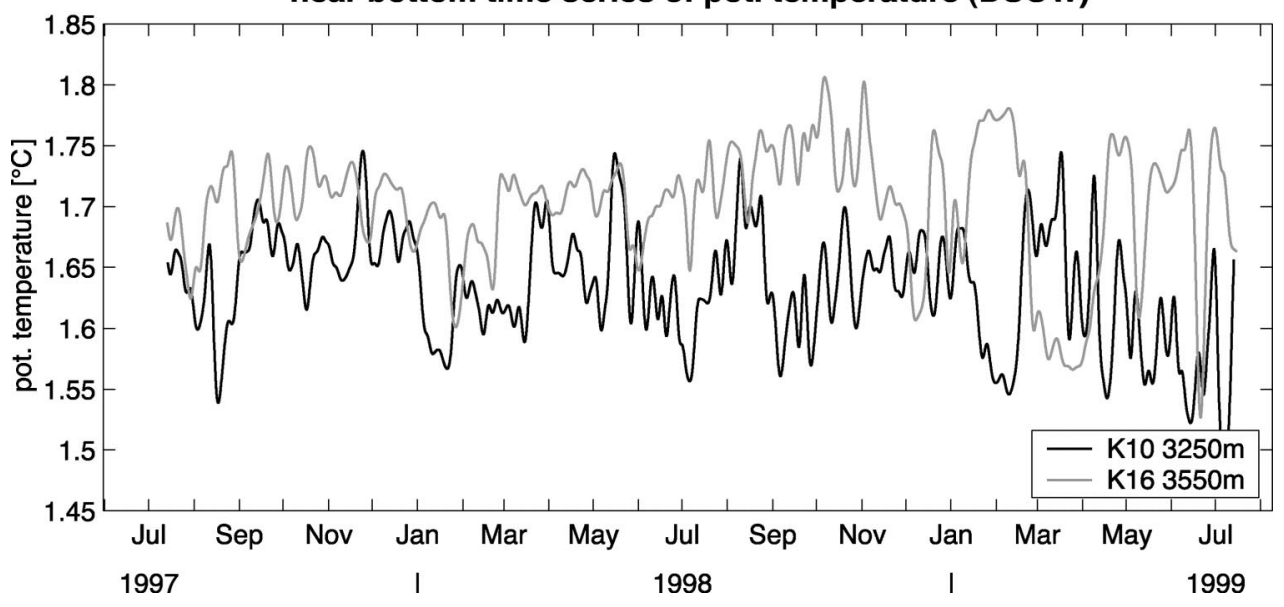

FIG. 8. Potential temperature at different levels from moorings K8, K9/19, K10, and K16.

not in the boundary current. Current speeds of the shallow Labrador Current (LC) increase during autumn and winter (Fig. 6, shallow records of moorings K7 and K8) and baroclinic adjustment led to deepening of isopynals (isotherms) during that period; that is, temperature rec- ords at intermediate depths show warming. At the end of the winter season (March/April) the LC decreases and the isotherms moved upward, causing a temperature decrease at intermediate levels.

The temperature records at $2500 \mathrm{~m}$ in the GFZW layer 
show a different picture. Both moorings K10 and K16 are located at the edge of the boundary current or in the reverse flow farther offshore. These records show rather stable temperature records around $2.7^{\circ} \mathrm{C}$. At $\mathrm{K} 9 /$ 19 the 2500-m temperatures are much lower at about $2.4^{\circ} \mathrm{C}$ and reveal larger variability. Here the LADCP data show the deep current core and an uplift of the isopycnals (Fig. 5) explaining the colder temperatures at this site.

In the DSOW layer we show two deep temperature records from moorings $\mathrm{K} 10$ and $\mathrm{K} 16$. The 3250-m record is located within the DSOW current core, while the deeper record at K16 is outside this core. Similar to what is observed in the GFZW layer, a trend could not be detected. This is also supported by the shipboard measurements analyzed by SKRSYK, which show rather little variability over the deployment period but drastic changes with much lower temperatures in 1996 and 2001. The general agreement between the two records is rather weak, and during the second half of the deployment period the temperatures appear to be anticorrelated-that is, in early 1999 when the DSOW transports are weak, as we will see later.

\section{e. Current variability}

The variability is discussed on the basis of spectra for higher-frequency variability and on harmonic analysis for the seasonal constituents.

\section{1) HIGH-FREQUENCY VARIABILITY}

A spectral decomposition of the intraseasonal variance has been performed for all moored records (Fig. 9); the focus is on periods ranging from 2 to 100 days in duration. There are several frequency bands with high energy, and with a tendency of a red energy shift toward the interior Labrador Sea. At the near-coastal mooring K7 (Fig. 9a), the highest near-surface variance is found at periods of 10 and 20 days with decreasing energy toward shorter and longer periods. At K8, a little farther offshore, the variance peaks at 5 and 10 days and the peak at 20-day periods reveals much less energy (about one-half) than that at K7. Farther offshore the variance decreases, as moorings K9/19 and K10 are located offshore of the Labrador Current regime. At these mooring locations the energy is concentrated at longer periods, above 20 days.

Within the LSW depth range (Fig. 9b) maximum variance is observed at the location of mooring K9/19 for periods between 10 and 20 days. The energy level at $\mathrm{K} 8$ is lower, but the maximum variability occurs at roughly the same periods. Both moorings are located in the core of the Deep Labrador Current (as will be discussed later). Farther offshore at mooring K10, located at the edge of the DLC, mean flow and variability are weak. The same is true for the mooring K16 which shows very weak flow in the direction opposite to the
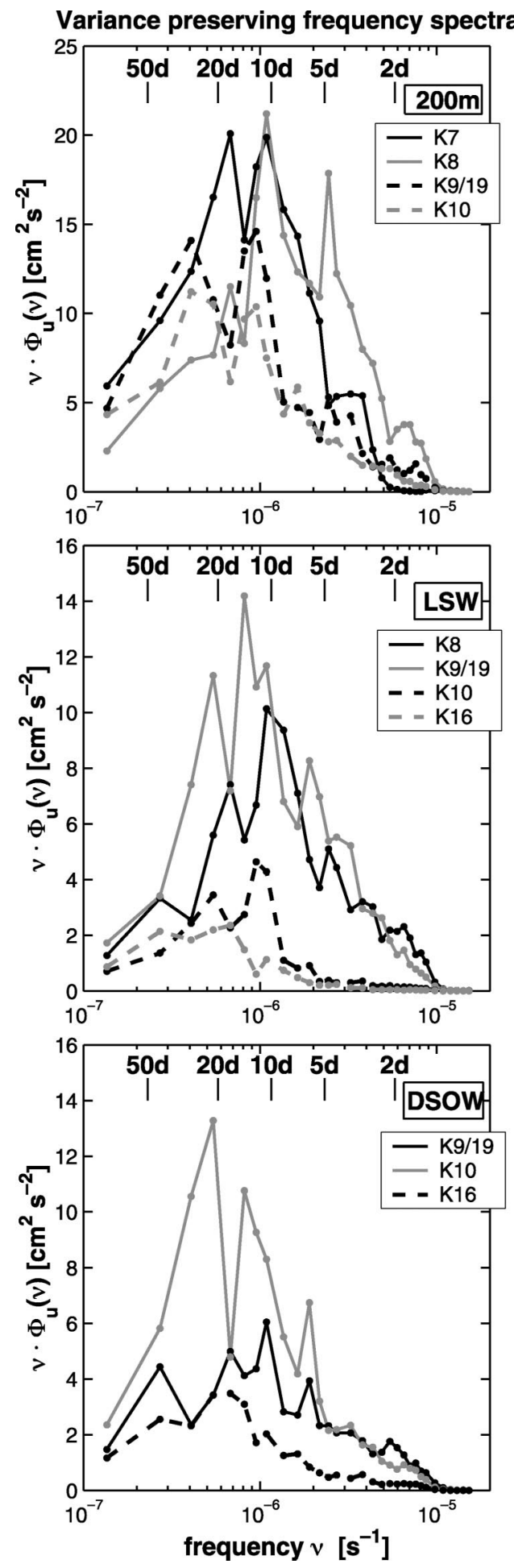

FIG. 9. Variance-conserving spectra of the alongshore flow; currents are detided (3-day low-pass filter) and spectra are calculated for overlapping pieces of 100-day duration (50 days overlap) for (a) upper-layer records, (b) 1500-m LSW records, and (c) the near-bottom flow. Line signatures are for mooring discrimination. 
DLC and low variance at periods above 10 days and almost no variability at higher frequencies.

Last, the DSOW core, shown by the spectra from the current records close to the bottom (Fig. 9c), shows maximum variability at mooring K10 and a peak at 20day periods. Farther inshore and offshore at K9/19 and $\mathrm{K} 16$, respectively, the variance of the deep flow is more than a factor of 2 less than at K10.

Mean eddy kinetic energy (EKE) for all current meter records is listed in Table 2. For the Labrador Current at 200-m depth, EKEs are on the order of $100 \mathrm{~cm}^{2} \mathrm{~s}^{-2}$, similar to what has been found in a recent high-resolution model (Eden and Böning 2002). In this model with $1 / 12$ resolution the Labrador Current shows an EKE peak in February, which can be attributed to baroclinic instability. Also discussed in their model is the origin of eddy activity in the interior Labrador Sea, which is predominantly caused by instabilities of the West Greenland Current and subsequent eddy propagation into the central Labrador Sea. This might be one reason for the observed frequency differences between near-coastal and offshore records.

\section{2) SEAsonal VARiability}

Seasonal variability of the alongshore flow is determined by harmonic analysis applied to the low-passfiltered (detided with a 3-day cutoff) time series (Fig. 10). The largest annual cycle with $7 \mathrm{~cm} \mathrm{~s}^{-1}$ amplitude is observed in the near surface layer at the shelf break (mooring K7). There, the Labrador Current variability is dominated by the annual cycle which accounts for $\sim 20 \%$ of the total variance in the detided time series. The annual phase shows an alongshore current maximum in November/December roughly coinciding with the annual maximum of the wind stress curl. Downward and offshore the annual amplitude decreases, such that the $1050-\mathrm{m}$ record at K7 basically shows no annual cycle with the annual amplitude being less than $2 \mathrm{~cm}$ $\mathrm{s}^{-1}$ and the explained variance below 5\%. However, the phases of the annual component of the three nearshore moorings all reveal the same phase. A region of low annual current variability extends outward from the topography to the location of mooring K10 and covers both, the LSW and GFZW range (Fig. 10). Absolute annual amplitudes are less than $2 \mathrm{~cm} \mathrm{~s}^{-1}$ in this regime and the explained variance is less than $10 \%$. A seasonal bias in deep transports derived from shipboard observations (Table 1) is therefore regarded as being negligible. However, an annual cycle is picked up again by the deepest records at mooring $\mathrm{K} 10$, that is associated with somewhat larger explained variance (15\%) and a $180^{\circ}$ phase shift relative to the annual phase of the Labrador Current.

\section{Transports}

\section{a. Mean boundary current flow and transports}

Deployment-long averages of the alongshore currents are the basis for the mean boundary current shown in
Fig. 11 (note, that some of the records in K9 were not continued in $\mathrm{K} 19$, such that a few records at this location are only one year long, especially the near-bottom records; see Table 2).

The mean alongshore flow (from summer 1997 to summer 1999) is then mapped on a fine mesh with a horizontal grid size of $5 \mathrm{~km}$ and a vertical cell size of $50 \mathrm{~m}$. The mapping was performed in two steps. First, a triangle-based linear interpolation was used to fill all grid points inside the array, and thereby also produced data points along the topography (roughly along the connection of the deepest instruments). Then, in a second step the gridded field was smoothed and extrapolated toward the topography by using two-dimensional Gaussian weights. The half-width of the Gaussian weights are $10 \mathrm{~km}$ horizontally and $150 \mathrm{~m}$ vertically, and the cutoff radii were $15 \mathrm{~km}$ and $250 \mathrm{~m}$, respectively. The resulting mean flow pattern (Fig. 11) is surprisingly similar to the boundary current obtained from the shipboard sections (Fig. 5); both fields are plotted with identical color coding. This similarity is not only qualitative, but also quantitative in terms of current speeds and layer transports (see also Table 1). Current cores are located at the same place, and in both fields an interior flow minimum is found near the shelfbreak and vertically near $\sigma_{\Theta}=27.80$ between LSW and GFZW. Total deepwater transports are 25.2 (array mean), 25.4 (combined LADCP data), and 23.2 Sv (referenced mean geostrophic flow), with the largest difference in the DSOW layer. For completeness, the upper layer transports are 12.0, 12.3, and 13.5 Sv, respectively; even these appear rather similar when taking possible seasonal biases of the upper-layer shipboard observations into account.

Unresolved near-bottom flows impose the largest uncertainties to any transport estimates of the deeper layers. Let us consider a thin and isolated current maximum associated with the DSOW core. The DSOW core is located near the position of moorings K9 and K19 with diffent instrumentation in the near-bottom layer. While mooring K9 (August 1997-July 1998) has its lowest current meter located $\sim 160 \mathrm{~m}$ above the bottom, its successor K19 had a current meter much closer to the bottom ( $\sim 50 \mathrm{~m}$ above the bottom). Inspection of the flow statistics (Table 2) reveals about $25 \%$ higher annual-mean flow at K9, which might be caused by either temporal variability or because of a current maximum above the bottom and current decay toward the seafloor. However, because the flow at $2400 \mathrm{~m}$ is also lower in the second (K19) than in the first year (K9), it is more likely a temporal phenomenon. Unfortunately, the shipboard observations are of little help to sort this out, because bottom interference in the LADCP data masks the very near bottom flow ( $\sim 80 \mathrm{~m}$ above the bottom are blanked out), and high-frequency variability in individual sections is larger than this difference.

Uncertainties of the transports due to this unresolved flow near the sloping bottom have the largest impact on the DSOW transport. For the mean field the contribution 


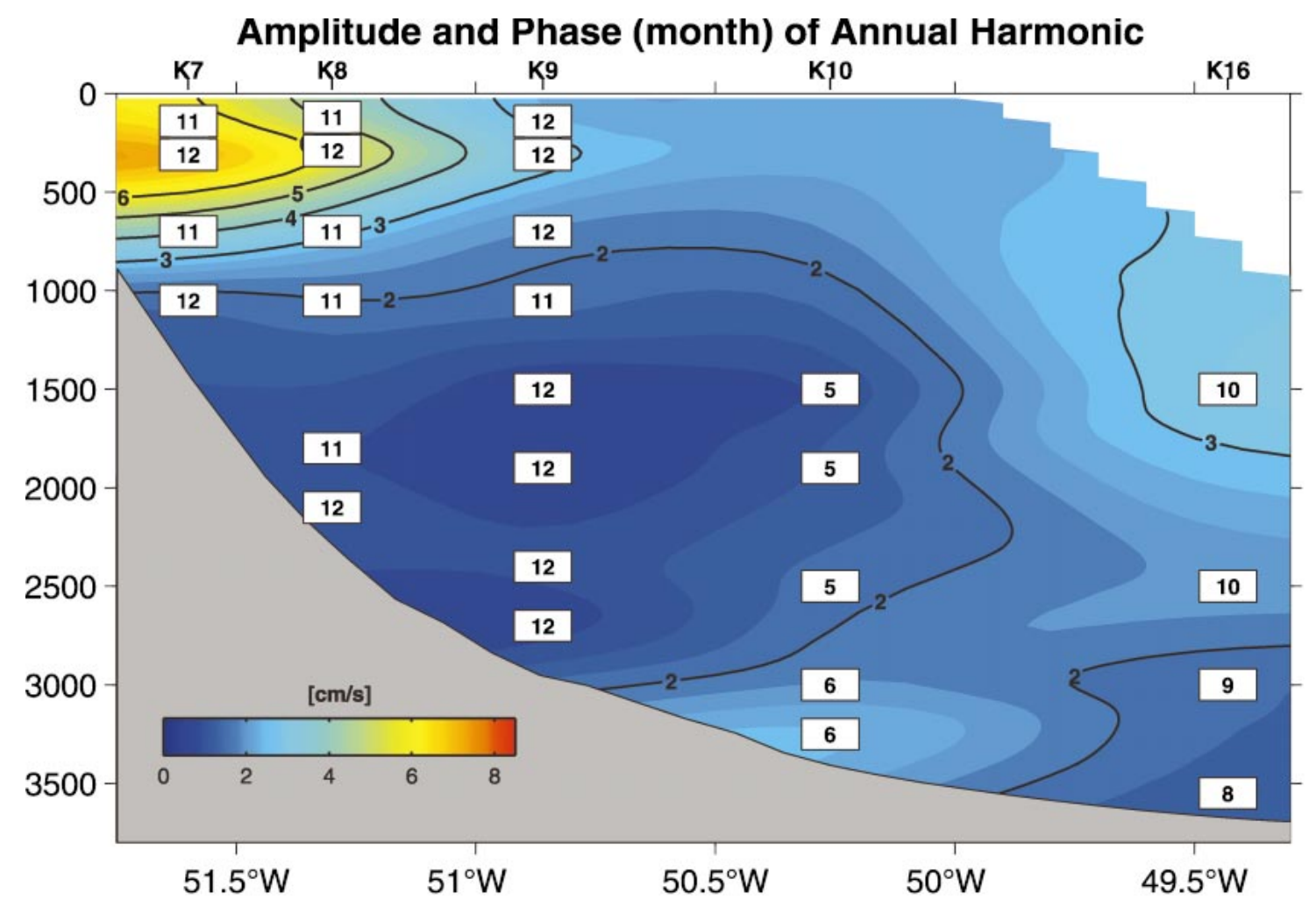

FIG. 10. Contoured amplitude of the annual harmonics $\left(\mathrm{cm} \mathrm{s}^{-1}\right)$ with phases of maximum southwestward flow (month of year) labeled.

of the extrapolated flow is 2.1 (DSOW), 0.6 (GFZW), and $0.7 \mathrm{~Sv}$ (LSW). Thus, for the DSOW layer about one-half of the transport is by extrapolation, while for the other two the contribution by extrapolation is less than $10 \%$.

\section{b. Transport time series}

Transport time series are calculated from the intersection of the isopycnal $\sigma_{\Theta}=27.74$ with the topography and out to the current reversal, that is, for the total deepwater range below $\sigma_{\Theta}=27.74$ (Fig. 12) and separately for the three NADW components LSW, GFZW, and DSOW (Fig. 13).

For each 10-day mean the current field was gridded using the same procedure and interpolation scales as for the mean field. Short-term variability with periods from weeks to months shows a large range of deep-water transports from about 15 (February 1999) to $35 \mathrm{~Sv}$ (October 1997) at a mean transport of $26.2 \mathrm{~Sv}$. For individual years the mean transport is $28.3 \mathrm{~Sv}$ in the first year and $24.2 \mathrm{~Sv}$ in the second year: a $17 \%$ decrease in mean transport in comparison with a standard deviation of 4.6 and 4.7 Sv for the two years. Based on the spectra we assume there are about 12 degrees of freedom (independent data every 30 days), such that the statistical uncertainty of the annual means would be approximately 1.5 Sv. Although the difference between the two annual means is not highly significant, the time series shows a trend toward lower transports until winter 1998/ 99 and some indication for increasing transports thereafter.

Mean isopycnal depths used for the transport calculations were calculated by averaging the three shipboard surveys of the $53^{\circ} \mathrm{N}$ section, carried out during the deployment period of the array. The depth of the deep isopycnals $\sigma_{\Theta}=27.80$ and $\sigma_{\Theta}=27.88$ was rather stable throughout the deployment, but the upper LSW boundary at $\sigma_{\Theta}=27.74$ deepened during that period. The LSW thickness along $53^{\circ} \mathrm{N}$ defined by the depth of the bounding isopycnals $\sigma_{\Theta}=27.74$ and $\sigma_{\Theta}=27.80 \mathrm{de}-$ creased by about $200 \mathrm{~m}$ over the deployment period (SKRSYK). In comparison with a mean LSW thickness of about $1200 \mathrm{~m}$ this behavior leads to underestimating the LSW transport during the first year by about $10 \%$ (by about $1 \mathrm{~Sv}$ ) and to overestimating it by the same amount during the second year when using a constant mean upper boundary.

The contribution of the baroclinic flow to the total deep-water transport is shown in Fig. 14. The baroclinic contribution was calculated relative to the mean depth of the isopycnal $\sigma_{\Theta}=27.80$, because this isopycnal is located near the flow minimum (Fig. 5) and was chosen as the upper boundary of the GFZW. This isopycnal was also used in earlier studies (Bacon 1997) on decadal 


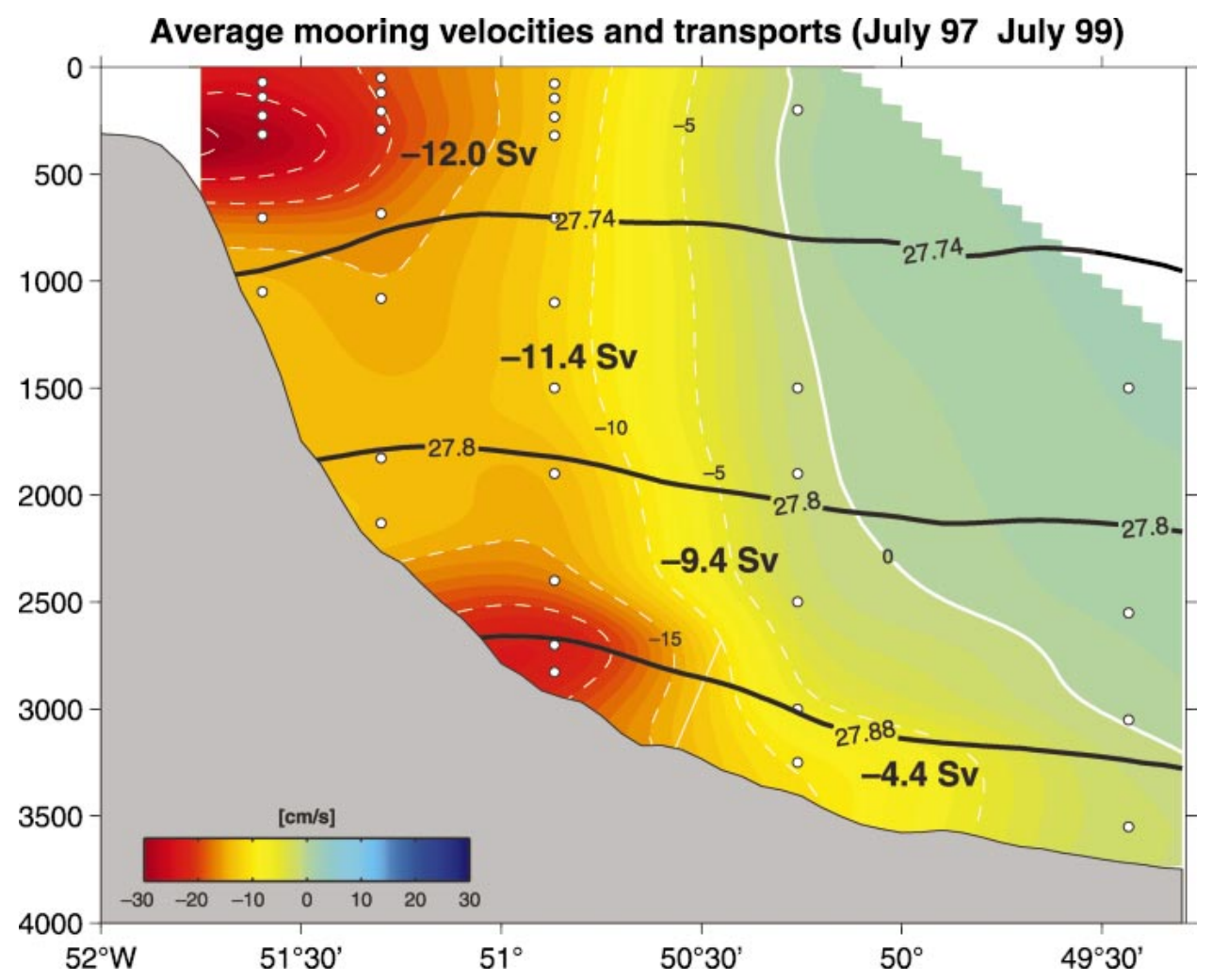

FIG. 11. Mean alongshore flow $\left(\mathrm{cm} \mathrm{s}^{-1}\right)$ for the period Aug 1997-Jul 1999 with currents color coded, water mass boundaries by isopycnals (black lines), and transports in Sverdrups (Sv) for layers labeled.

circulation variability that were based on geostrophic sections.

As the layer around the reference level and the whole GFZW layer shows weak vertical shear, the baroclinc transport contribution of $2.7 \mathrm{~Sv}$ GFZW is small (20\%) compared to the total transport of that layer $(9.7 \mathrm{~Sv})$. This is different for the DSOW where the baroclinic part contributes about $60 \%$ to the total, and for the combined deep-water transport the baroclinic fraction is about $30 \%$ of the total. The transport variability of the combined deep-water layer is also sufficiently different with a range of about $5 \mathrm{~Sv}(3-8 \mathrm{~Sv})$ in the baroclinic part and between 10 and $20 \mathrm{~Sv}$ for the total transport range; standard deviations differ by a factor of 2 .

By just looking at the baroclinic transport variability we observe the full 5-Sv transport range being covered within a month. However, shipboard boundary current sections presented here and elsewhere just take a few days and represent a synoptic snapshot of this high frequency variability. This may cause severe aliasing problems when comparing individual section transports from different years with regard to interannual variability. Further, a correlation of the baroclinic contribution and the total transport is seen in the DSOW layer, but not in the overlying GFZW range. An estimate of the total transport from the knowledge of the baroclinic contribution alone would therefore be difficult to achieve.

\section{Interior recirculation}

The shallower records at mooring K10 and the currents at K16 exhibit weak currents towards northerly directions, that is, in the reverse direction to the boundary current. These moorings are located at the inshore edge of the anticyclonic recirculation cell first described for the mid-depth circulation in Lavender et al. (2000) and confirmed by Cuny et al. (2002), which has its origin farther south near $51^{\circ} \mathrm{N}$ (Fischer and Schott 2002). This cell extends to the surface circulation and is also visible in surface drifters (Reverdin et al. 2003). Although the moored array is not adequate to determine the transport of the recirculation cell, we provide an estimate on the basis of the shipboard observations. The width of the cell is about $100 \mathrm{~km}$, and the $1500-\mathrm{m}$ record at K16 shows $2.5 \mathrm{~cm} \mathrm{~s}^{-1}$ on average. For a LSW layer thickness of $1300 \mathrm{~m}$ this yields $3.3 \mathrm{~Sv}$ as a lower limit. The LADCP data from the time period 1996-2001 were combined to yield the mean boundary current structure and the recirculation (Fig. 5a and Table 1). For the LSW layer the mean recirculation transport from the LADCP data is somewhat higher than this rough estimate, at 5.6 $\mathrm{Sv}$, as the mooring location of K16 is shoreward of the flow maximum. In the GFZW depth range the moored records in K16 showed even weaker mean flow, which is also consistent with the slanting structure of the re- 
total deep water transport $\left(\sigma_{\theta}>\mathbf{2 7 . 7 4}\right)$ at $53^{\circ} \mathrm{N}$

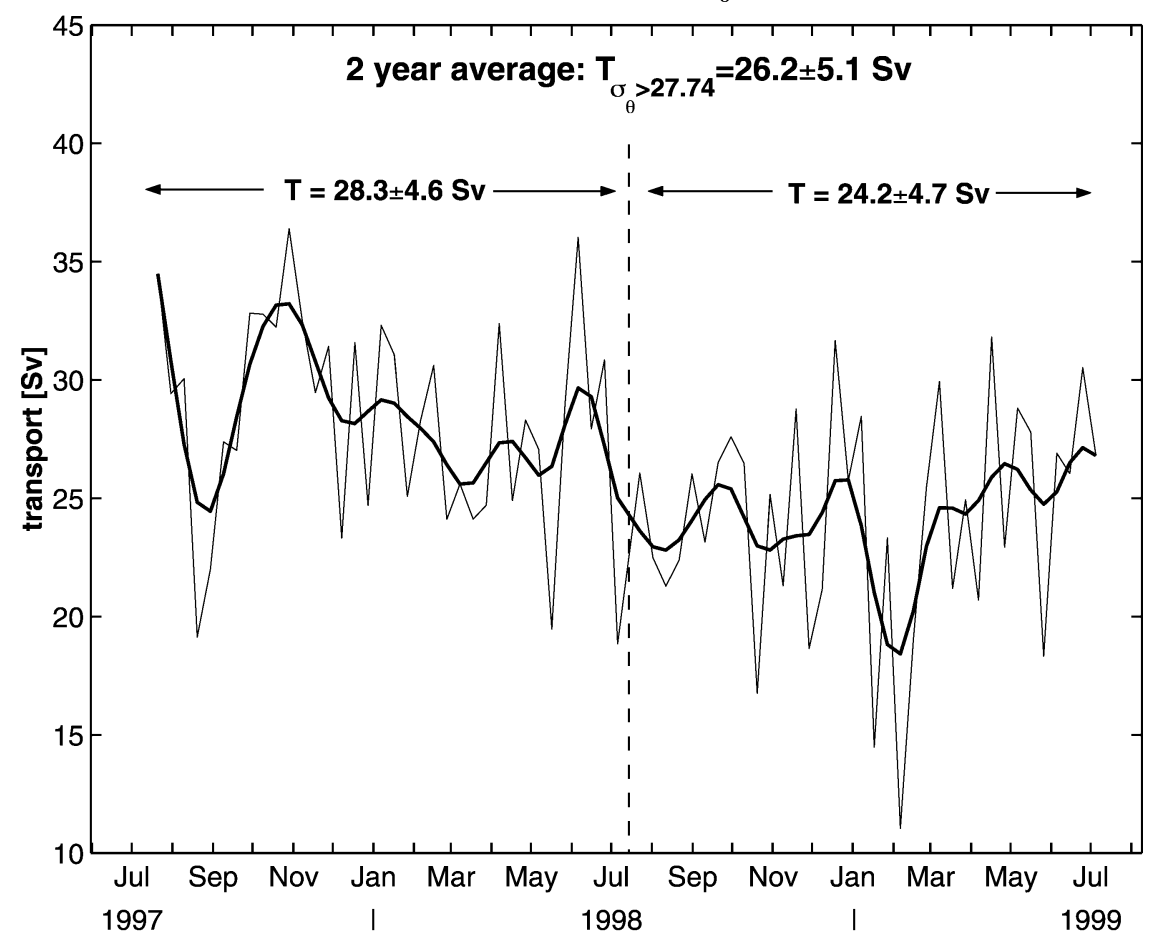

FIG. 12. Time series of total deep-water transports into the boundary current direction and below $\sigma_{\Theta}=27.74$; thin lines for 10-day mean flow and heavy lines for low-pass-filtered transport time series (cutoff at 60-day periods). Annual mean transports and standard deviations are included.

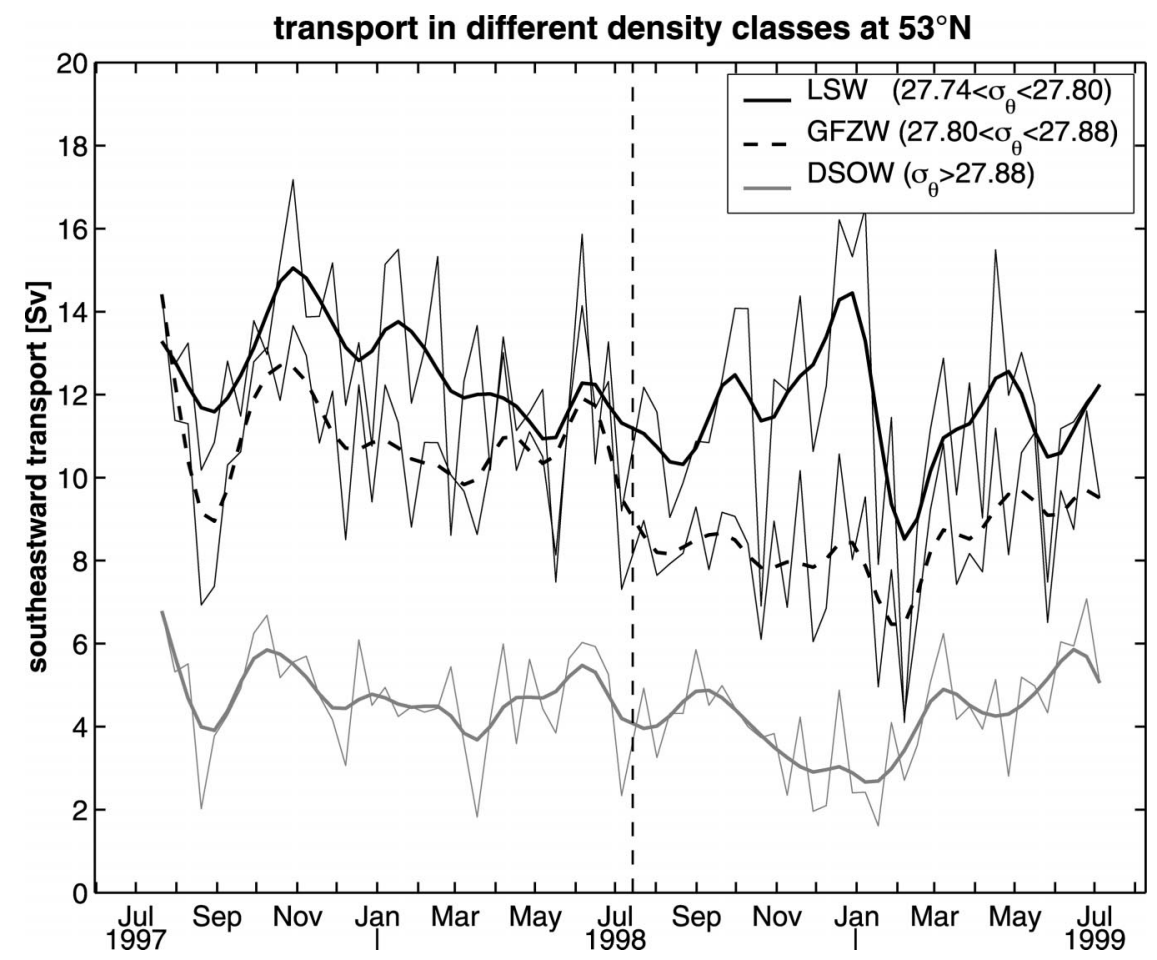

FIG. 13. Time series of boundary current transports for LSW, GFZW, and DSOW layer; thin lines for 10-day mean flow and heavy lines for low-pass-filtered transport time series (cutoff at 60-day periods). 

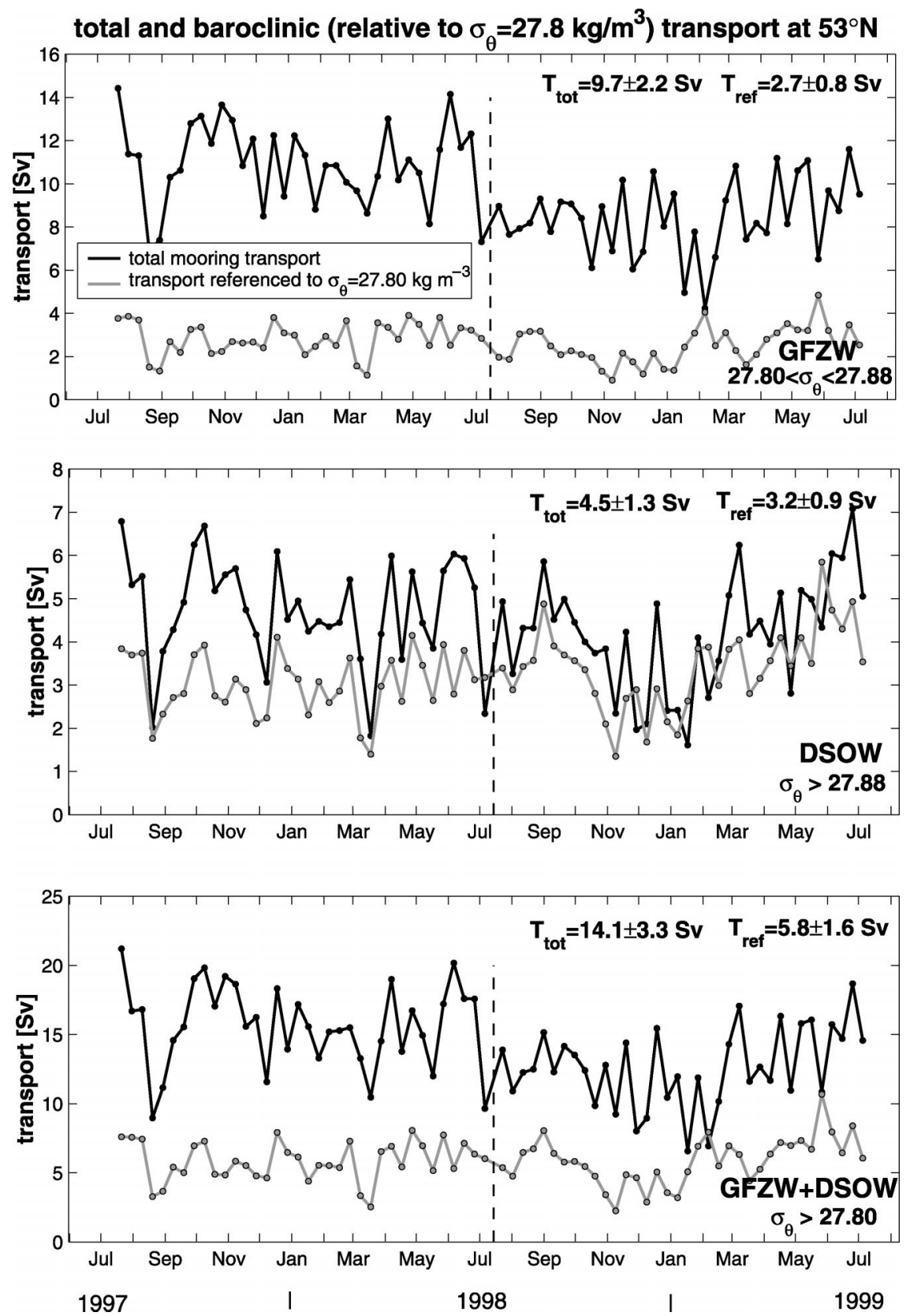

FIG. 14. Time series of boundary current transports for GFZW and DSOW layers; for the total transport (heavy line) and for the baroclinic contribution relative to $\sigma_{\Theta}=27.80$ (thin line). Density ranges and mean transports are labeled.

circulation at that location. For the sum of all deepwater masses below the average depth of $\sigma_{\Theta}=27.74$ the recirculation transport is $9.6 \mathrm{~Sv}$.

Geostrophic transports for the deep-water masses are listed in Table 1, and these are only a little lower than those from the LADCP and current-meter data and all three estimates agree within the error bounds resulting from the high frequency variability. For the recirculation at the $53^{\circ} \mathrm{N}$ section the agreement between transports derived from referenced geostrophic currents and
LADCP data is also very good, at $9.2 \mathrm{~Sv}$ for geostrophy as compared with 9.6 from the LADCP data. Although all section data were from summer surveys it appears that the recirculation is a stable circulation feature near the exit of the Labrador Sea; there is not much of a seasonal cycle in the few current-meter records available for this regime.

Another interesting question is whether there is a transformation of the water masses flowing southward with the boundary current and those recirculating. The 
1500-m floats show warmer water flowing northward in the interior, but this might be just the expression of the general baroclinic structure (Fischer and Schott 2002). However, inspection of the $T-S$ diagrams at $53^{\circ} \mathrm{N}$ (Fig. 15) shows that there are isopycnic $T / S$ gradients with colder and fresher water in the boundary current and more saline and warmer in the recirculation path. For better discrimination, the data from the shelf edge to the current maximum at $2500 \mathrm{~m}$ are shown in red, those from the current maximum to the zero crossing at 3300 $\mathrm{m}$ are in green, and $T-S$ profiles in the recirculation are shown in blue. Comparing the two realizations from summer 1998 and summer 1999, the $T / S$ gradients in the LSW range are larger in the first year (e.g., along $\left.\sigma_{\Theta}=27.74\right)$, while at the GFZW level both years show similar $T / S$ differences between the $\mathrm{BC}$ and the recirculation.

A possible explanation of this behavior is the difference in convection activity in the central Labrador Sea where in March 1997 relatively deep convection down to $1500 \mathrm{~m}$ was observed, whereas the winters before and after 1997 had shallower convection depth not reaching the 1500-m level. Although we are not able to observe closed recirculation cells, we might get a rough idea of how long a water particle needs to pass the $53^{\circ} \mathrm{N}$ array and return to that section in the recirculation path. Profiling floats (Fischer and Schott 2002) drifting along that recirculation route needed somewhat less than one year to arrive again at the $53^{\circ} \mathrm{N}$ section.

These recirculation cells appear to be important for the formation and export of LSW. Pickart et al. (2002) showed that the deepest convection in winter 1996/97 occurred in the trough of the northwestern recirculation cell. The southern cell described here has an impact on the net export of LSW, but it may also play a role in supplying the central Labrador Sea with relatively warm and salty water originating from near the Northwest Corner of the NAC.

\section{Summary}

From the comprehensive observations of recent years a detailed picture of the deep flow in the southern Labrador Sea evolved. Presented here is a full ocean depth analysis of the Deep Labrador Current including all three deep-water masses, LSW, GFZW, and DSOW, and their transports. The major results of this investigation are

- There is a well-defined deep boundary current with maximum alongshore flow in the LSW layer located at about 2500-2800-m water depth.

- A level of no motion does not exist in either the boundary current regime or in the recirculation path.

- There is an intense deep current core associated with DSOW located at about 3000-3500-m water depth.

- The total deep-water transport in the boundary current direction during the period from 1997 to 1999 is 26 $\pm 5 \mathrm{~Sv}$.

- Northwestward recirculation offshore from the boundary current (Lavender et al. 2000) has been estimated at about $9 \mathrm{~Sv}$ for the combined deep-water range (LSW, GFZW, and DSOW) by LADCP measurements and referenced geostrophic currents.

- A seasonal cycle is confined to the shallow Labrador Current, which decreases with depth and offshore distance and is negligible in the LSW layer.

- Intraseasonal variability dominates the boundary current at all depths at periods ranging from 5 to 30 days and leads to significant transport variability at short time scales.

\section{Discussion}

\section{a. Forcing variability}

Besides the role of the wind field in the generation and strength of the recirculation cells in the Labrador Sea (Käse et al. 2001; Spall and Pickart 2003), the variations of the large-scale wind forcing has been investigated by Eden and Willebrand (2001). In this study a fast (intraseasonal) barotropic response of the circulation and a delayed baroclinic response was found to be related to the variability of the North Atlantic Oscillation (NAO). Their time span (1958-96) did not extend into our observational period, and a direct comparison is not possible. However, the thermohaline circulation variability in the Labrador Sea was $O(1-2 \mathrm{~Sv})$ only, with a 2-3-yr delay to the NAO.

The large-scale wind stress curl over the Labrador and Irminger Seas shows a pronounced annual cycle with maximum cyclonic curl in winter (Fig. 16a). This annual maximum varies on interannual time scales as is shown in Fig. 16b. Here the mean annual cycle of the period shown is subtracted and the anomalous curl is then low-pass filtered (2-yr cutoff). The result shows that the observational period (summer 1997-summer 1999) has larger-than-average wind stress curl after a few years with lower-than-average conditions. Especially the two winter periods (1997/98 and 1998/99) show significantly larger values than the period before and thereafter.

The largest variability of the Deep Labrador Current is concentrated at periods less than two months. Furthermore, this high-frequency variability is not constant during the seasons, but shows EKE enhancements in late winter. The EKE maximum in the central Labrador Sea seen in altimeter data (Brandt et al. 2004) seems to be isolated from the boundary current regime by areas of low EKE just offshore. Different from the barotropic instabilities of the West Greenland Current the dominant EKE source of the Labrador Current in the $1 / 12^{\circ}$-resolution model of Eden and Böning (2002) are baroclinic instabilities, suggesting that the high-frequency vari- 

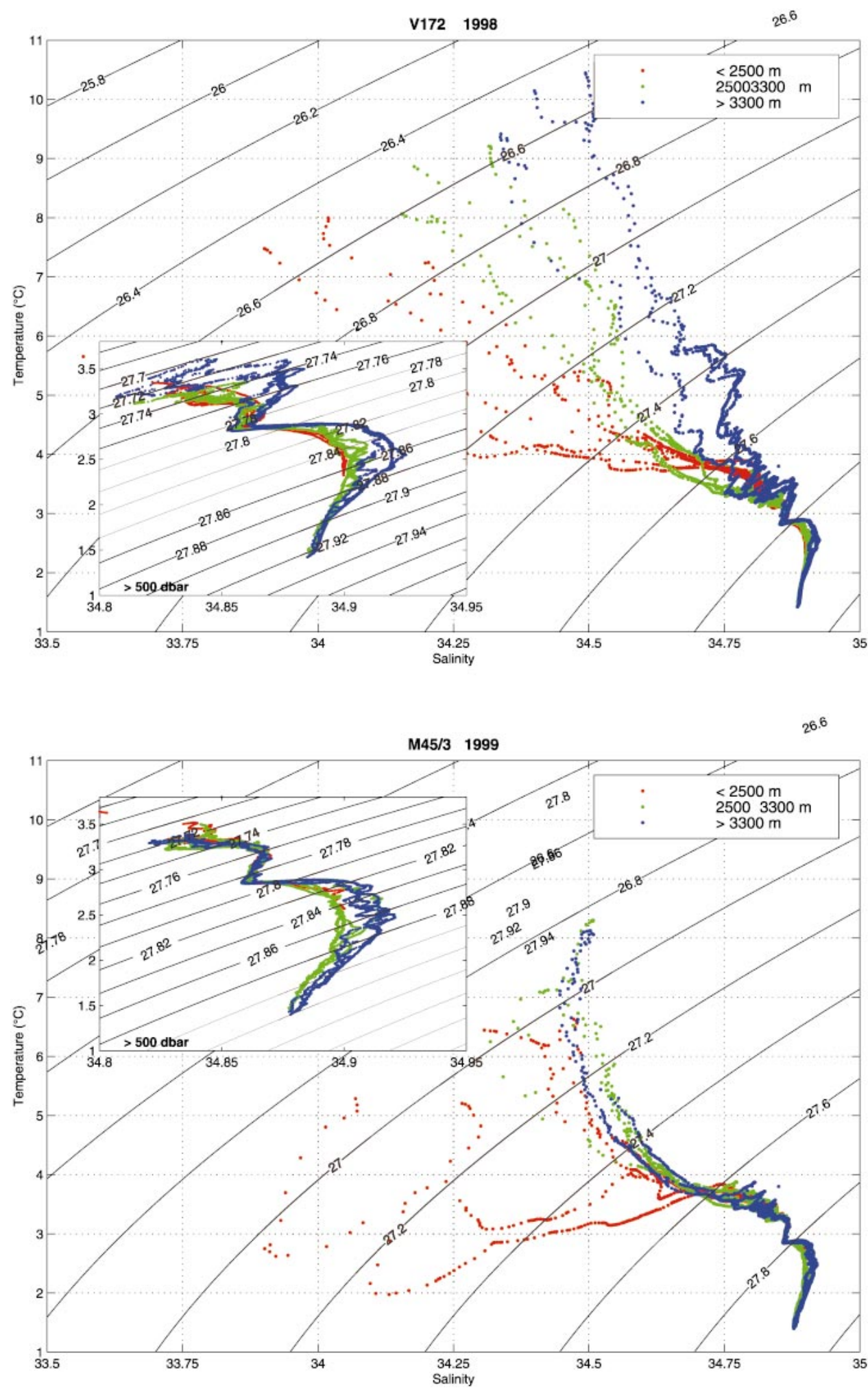

FIG. 15. The $T-S$ diagrams from stations along the moored array near $53^{\circ} \mathrm{N}$ for (a) RV Valdivia cruise in summer 1998 and (b) RV Meteor cruise in summer 1999. Color coding is for location of the $T-S$ diagrams relative to the boundary current; red for profiles between the shelf break and the current maximum at 2500$\mathrm{m}$ depth, green for profiles from the current maximum to the edge of the boundary current at 3300-m water depth, and blue for the recirculation. 

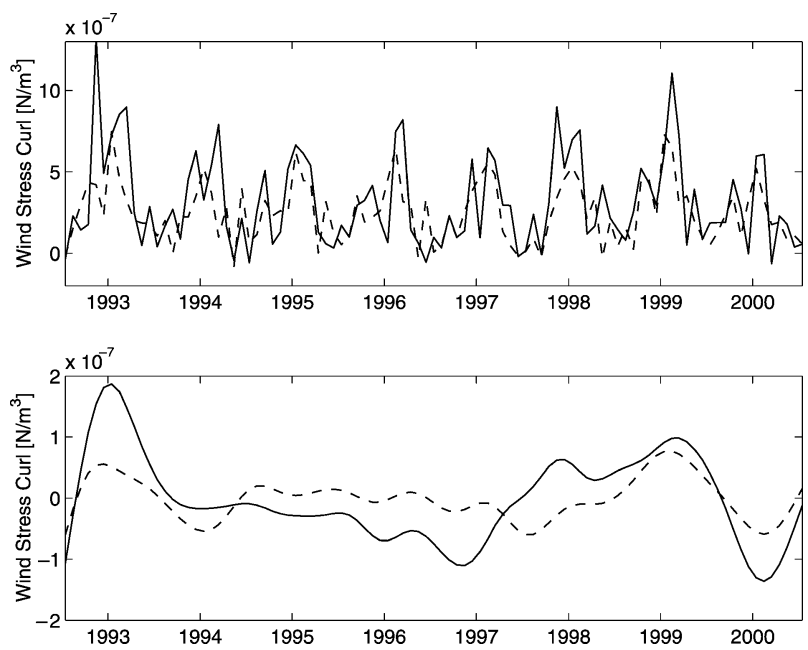

FIG. 16. Time series of (a) the wind stress curl over the Labrador Sea (solid) and Irminger Sea (dashed) and (b) the low-pass-filtered wind stress curl anomaly (mean annual cycle eliminated).

ability seen in the current-meter records is generated by instabilities of the boundary current itself.

\section{b. The DWBC in the western subpolar North Atlantic}

A very interesting question is whether there is a continuous DWBC in the western subpolar North Atlantic that connects the subpolar regime with the subtropics from the Irminger Sea to the Labrador Sea and around the Grand Banks.

In a recent inverse study by Lumpkin and Speer (2003) the deep-water transport across $60^{\circ} \mathrm{N}$ (at Cap Farvel, Greenland) was determined to be $13.1 \pm 1.7 \mathrm{~Sv}$ for densities $\sigma_{\Theta}>27.80$, which is consistent with earlier findings by Dickson and Brown (1994). For the same density range we obtain a combined DSOW and GFZW transport of $14.1 \pm 3.3 \mathrm{~Sv}$ from the moored array at $53^{\circ} \mathrm{N}$, which indicates a continuous deep-water flow through the Labrador Sea with not much transport added along its path.

Farther along the DWBC pathway, at the Labrador shelf break, annual velocity variations of the Labrador Current were studied by Lazier and Wright (1993). Their investigation was based on CTD sections (from 1978 to 1988) perpendicular to the shelf near Hamilton Bank (the later WOCE AR7W section and a section just southeast of Hamilton Bank) and on current-meter records around Hamilton Bank (from 1979 to 1988). The baroclinic flow relative to 1500 dbar exhibits a general structure similar to what is found here, namely, the baroclinic Labrador Current at the shelf edge and a deep current core with DSOW properties at depths below $3000 \mathrm{~m}$. Maximum flow in the LSW layer is located at 2500-m water depth, seaward of the traditional Labrador Current and with weak vertical shear. The record from mooring M8 (Lazier and Wright 1993, their Fig. 9) is included in Fig. 3 (the square at $2500 \mathrm{~m}$ ) as a linear interpolation between the weakly sheared 1000-m and 2200-m records. This value matches the boundary current structure determined from the $1500 \mathrm{~m}$ floats very well, and might be taken as an indication of low interannual boundary current variability (1987/88 as compared with 1997/99). Further, the 3300-m isobath terminates the offshore extension of the Deep Labrador Current at Hamilton Bank (mooring M9 of Lazier and Wright 1993) and at $53^{\circ} \mathrm{N}$ (this study).

From the winter survey in 1997 Pickart et al. (2002) calculated boundary current transports from three individual LADCP sections north of Hamilton Bank, that is, upstream of the $53^{\circ} \mathrm{N}$ section. Total equatorward transports were between 43.2 and 49.9 Sv north of Hamilton Bank as compared with our LADCP mean of 37.7 $\mathrm{Sv}$ and the current-meter mean transport of $40.3 \mathrm{~Sv}$. However, this is the top-to-bottom transport, and a different section extension toward the shelf might account for a few additional Sverdrups. Further, it is interesting to note that the western sections (Pickart et al. 2002) also reveal a deep DSOW current core and a weak indication of reverse flow about $150 \mathrm{~km}$ off the $1500-\mathrm{m}$ isobath. Using the 3000-m isobath as the dividing line between the boundary and the interior gyre water masses, the authors argue that $11.9 \mathrm{~Sv}$ should recirculate and the boundary current throughflow is on the order of $28 \mathrm{~Sv}$.

On a larger scale the profiling floats showed a continous middepth circulation around the periphery of the Labrador Sea and several robust recirculation cells offshore of the boundary current (Lavender et al. 2000). Evidence of the southern cell near the exit of the Labrador Sea is also found in Lazier and Wright (1993) along a geostrophic section just south of Hamilton Bank and in individual 1500-m trajectories of profiling floats (Fischer and Schott 2002). Such recirculation cells are also present in recent modeling efforts. Käse et al. (2001) obtained strong interior recirculation in the Labrador Sea in a high-resolution model forced by a wind field obtained from a global assimilation study. The structure of their recirculation cells is similar to what has been observed, but the transports associated with the cell at $53^{\circ} \mathrm{N}$ are somewhat larger (about $20 \mathrm{~Sv}$ ) than those of the observations (10-14 Sv for full ocean depth). Much weaker recirculation cells with transports $O(2-3 \mathrm{~Sv})$ are generated in the model study of Spall and Pickart (2003). In their study the recirculation cells were primarily forced by the wind field along the east Greenland coast, while in Käse et al. (2001) wind forcing along the margins and northern overflows play an important role for the strength of the recirculations

However, after leaving the Labrador Sea, none of the floats directly deployed in the Deep Labrador Current (Fischer and Schott 2002) and at other locations in the Labrador Sea (Lavender et al. 2000) exited the subpolar gyre via the DWBC pathway at the tail of the Grand Banks. The float trajectories (Fischer and Schott 2002; Schott et al. 2004) and the chlorofluorocarbon studies 
(Rhein et al. 2002; Böning et al. 2003) show spreading pathways into the eastern basin, a narrow vein along the DWBC path at the Grand Banks (in the CFC data), but also indicate southward spreading of LSW (1500$m$ depth) within the Newfoundland Basin near the MidAtlantic Ridge.

Last, it is interesting to compare the transports of the Deep Labrador Current with the DWBC at the transition between the subpolar gyre and the subtropics. Schott et al. (2004) determined the southward cold water transport at the tail of the Grand Banks near $42^{\circ} \mathrm{N}$ from two moored arrays. The first array was deployed from 1993 to 1995 (A. Clarke, Bedford Institute of Oceanography, WOCE ACM7 array) and the second (IFM-Kiel array) was from 1999 to 2001 . In both realizations the cold water transport of the DWBC inshore of the NAC and below $\sigma_{\Theta}=27.74$ was about $12 \mathrm{~Sv}$. If we compare this number with the net boundary transport at $53^{\circ} \mathrm{N}$ that is about $26 \mathrm{~Sv}$ for the DLC and $\sim 9 \mathrm{~Sv}$ return flow, yielding $\sim 17 \mathrm{~Sv}$, the export out of the Labrador Sea is about 5 Sv larger. This difference applies equally to the LSW and GFZW, while the transports in the DSOW layer are about the same.

Farther south around the tail of the Grand Banks Pickart and Smethie (1998) determined the deep-water transport from absolute geostrophic sections to be $13.3 \mathrm{~Sv}$ below $\sigma_{\Theta}=27.80$. Their measurements were from four sections along $55^{\circ} \mathrm{W}$ that were occupied between 1983 and 1995. Adding the LSW transport (below $\sigma_{\Theta}=$ 27.74) yields $16.9 \mathrm{~Sv}$ flowing equatorward. This is similar to what has been obtained here, when subtracting the interior Labrador Sea recirculation from the DLC transport, but is significantly larger than the values obtained from the long-term current-meter averages of $\mathrm{SCH}$.

\section{c. Future}

This project started in 1996 and will be continued for several more years. A somewhat reduced array was in the water until summer 2003 and a single mooring was redeployed for another two-year period. This will enable us to look for climate signals in the deep-water characteristics of the boundary current and related transport variability. Further, the simultaneous mooring activity near the transition between the subpolar and subtropical gyre (Schott et al. 2004) will give the opportunity to relate the variability observed in the Labrador Sea to what is exported out of the subpolar gyre.

Acknowledgments. We thank captain and crew of RV Meteor as well as U. Papenburg and M. Müller of IFMKiel for their professional help during deployment and retrieval of the moored array. We also thank P. Brandt for providing the large-scale wind stress curl, and C. Mertens for many discussions and his help with some of the figures. Detailed comments of two anonymous reviewers are greatly appreciated. This work was sup- ported by the German Science Foundation (DFG) as part of the "Sonderforschungsbereich" SFB-460, Dynamics of the Thermohaline Circulation Variability.

\section{REFERENCES}

Bacon, S., 1997: Decadal variability of the North Atlantic Overflows. International WOCE Newsletter, No. 26, WOCE International Project Office, Southampton, United Kingdom, 29-30.

Böning, C. W., M. Rhein, J. Dengg, and C. Dorow, 2003: Modeling CFC Inventories and formation rates of Labrador Sea Water. Geophys. Res. Lett., 30, 1050, doi:10.1029/2002GL014855.

Brandt, P., F. Schott, A. Funk, and C. S. Martins, 2004: Seasonal to interannual variability of the eddy field in the Labrador Sea from satellite altimetry. J. Geophys. Res., 109, 2028, doi:10.1029/ 2002JC001551.

Cuny, J., P. B. Rhines, P. P. Niiler, and S. Bacon, 2002: Labrador Sea Boundary Currents and the fate of the Irminger Sea Water. $J$. Phys. Oceanogr., 32, 627-647.

Davis, R. E., 1991: Observing the general circulation with floats. Deep-Sea Res., 38, 531-571.

Dickson, R. R., and J. Brown, 1994: The production of North Atlantic Deep Water: Sources, rates and pathways. J. Geophys. Res., 99 (C6), 12 319-12 341.

__ J. R. N. Lazier, J. Meincke, P. Rhines, and J. Swift, 1996: Longterm coordinated changes in the convective activities of the North Atlantic. Progress in Oceanography, Vol. 38, Pergamon, 241-295.

Eden, C., and J. Willebrand, 2001: Mechanism of interannual to decadal variability of the North Atlantic circulation. J. Climate, 14, 2266-2280.

- , and C. Böning, 2002: Sources of eddy kinetic energy in the Labrador Sea. J. Phys. Oceanogr., 32, 3346-3363.

Fischer, J., and M. Visbeck, 1993: Deep velocity profiling with selfcontained ADCPs. J. Atmos. Oceanic Technol., 10, 764-773.

__ , and F. A. Schott, 2002: Labrador Sea Water tracked by profiling floats-From the boundary current into the open North Atlantic. J. Phys. Oceanogr., 32, 573-584.

Jakobsen, P. K., M. H. Ribergaard, D. Quadfasel, T. Schmith, and C. W. Hughes, 2003: Near-surface circulation in the northern North Atlantic as inferred from Lagrangian drifters: Variability from the mesoscale to interannual. J. Geophys. Res., 108, 3251, doi: 10.1029/2002JC001554.

Käse, R. H., A. Biastoch, and D. B. Stammer, 2001: On the middepth circulation in the Labrador and Irminger Seas. Geophys. Res. Lett., 28, 3433-3436.

The Lab Sea Group, 1998: The Labrador Sea deep convection experiment. Bull. Amer. Meteor. Soc., 79, 2033-2058.

Lavender, K. L., R. E. Davis, and W. B. Owens, 2000: Mid-depth recirculation observed in the interior Labrador and Irminger Seas by direct velocity measurements. Nature, 407, 66-69.

Lazier, J. R. N., 1980: Oceanographic conditions at Ocean Weather Ship “Bravo," 1964-1974. Deep-Sea Res., 18, 227-238.

__ 1988: Temperature and salinity changes in the deep Labrador Sea, 1962-1986. Deep-Sea Res., 35, 1247-1253.

- , and D. G. Wright, 1993: Annual velocity variations in the Labrador Current. J. Phys. Oceanogr., 23, 659-678.

—, R. Hendry, A. Clarke, I. Yashayaev, and P. Rhines, 2002: Convection and restratification in the Labrador Sea, 1990-2000. Deep-Sea Res., 49A, 1819-1835.

LeProvost, C., M. L. Genco, and F. Lyard, 1994: Spectroscopy of the world ocean tides from a finite element hydrodynamic model. J. Geophys. Res., 99, 24 777-24 797.

Loder, J. W., B. Petri, and G. Gawarkiewicz, 1998: The coastal ocean off northeastern North America: A large-scale view. The Sea, A. Robinson and K. Brink, Eds., The Global Coastal Ocean, Vol. 11, John Wiley and Sons, 105-133.

Lohmann, K., 1999: Gezeitenkorrektur von schiffsgestützten Strö- 
mungsmessungen. Master's thesis, Institut für Meereskunde an der Universität Kiel, 76 pp.

Lumpkin, R., and K. Speer, 2003: Large-scale vertical and horizontal circulation in the North Atlantic Ocean. J. Phys. Oceanogr., 33, 1902-1920.

Narayanan, S., S. Prinsenberg, and P. C. Smith, 1996: Current meter observations from the Labrador and Newfoundland shelves and comparisons with barotropic model predictions and IIP surface currents. Atmos.-Ocean, 34, 227-255.

Petrie, B., and J. Buckley, 1996: Volume and freshwater transport of the Labrador Current in Flemish Pass. J. Geophys. Res., 101 (C12), 28 335-28 342.

Pickart, R. S., and W. M. Smethie, 1998: Temporal evolution of the deep western boundary current where it enters the sub-tropical domain. Deep-Sea Res., 45, 1053-1083.

— M. A. Spall, and J. R. N. Lazier, 1997: Mid-depth ventilation in the western boundary current system of the sub-polar gyre. Deep-Sea Res., 44, 1025-1054.

- D. D. J. Torres, and R. A. Clarke, 2002: Hydrography of the Labrador Sea during active convection. J. Phys. Oceanogr., 32, 428-457.

Reverdin, G., P. P. Niiler, and H. Valdimarsson, 2003: North Atlantic Ocean surface currents. J. Geophys. Res., 108, 3002, doi: 10.1029/2001JC001020.
Rhein, M., and Coauthors, 2002: Labrador Sea Water: Pathways, CFC-inventory, and formation rates. J. Phys. Oceanogr., 32, 648-665.

Schmitz, W. J. J., and M. S. McCartney, 1993: On the North Atlantic Circulation. Rev. Geophys., 31, 29-49.

Schott, F. A., J. Fischer, R. Zantopp, M. Dengler, L. Stramma, and M. Wibaux, 2004: Currents and transports at the western exit of the subpolar North Atlantic. J. Phys. Oceanogr., 34, 817-843.

Smethie, W. M., and J. H. Swift, 1989: The tritium:krypton-85 age of Denmark Strait overflow, water and Gibbs Fracture Zone water just south of Denmark Strait. J. Geophys. Res., 94, 82658275 .

Spall, M. A., and R. S. Pickart, 2003: Wind-driven recirculations and exchange in the Labrador and Irminger Seas. J. Phys. Oceanogr., 33, 1829-1845.

Stramma, L., D. Kieke, M. Rhein, F. A. Schott, I. Yashayaev, and K. P. Koltermann, 2004: Recent deep water changes at the western boundary of the subpolar North Atlantic. Deep-Sea Res., in press.

Straneo, F., R. S. Pickart, and K. Lavender, 2003: Spreading of Labrador sea water: An advective-diffusive study based on Lagrangian data. Deep-Sea Res., 50, 701-719.

Talley, L. D., and M. S. McCartney, 1982: Distribution and circulation of Labrador Sea Water. J. Phys. Oceanogr., 12, 1189-1205. 